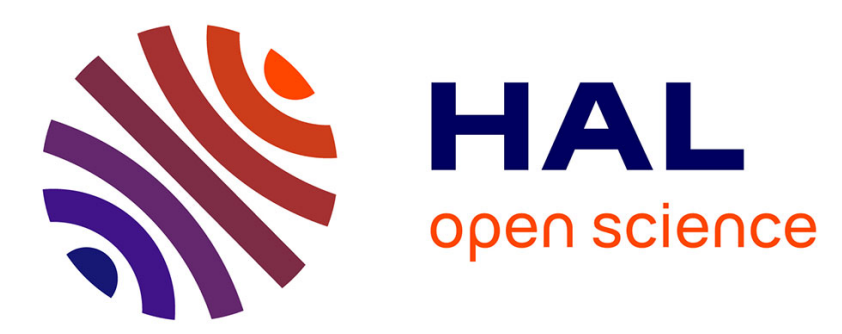

\title{
Comparison of biofilm development on three building and restoration stones used in French monuments
}

Stéphanie Eyssautier-Chuine, Nathalie Vaillant-Gaveau, Emilie Charpentier, Fany Reffuveille

\section{- To cite this version:}

Stéphanie Eyssautier-Chuine, Nathalie Vaillant-Gaveau, Emilie Charpentier, Fany Reffuveille. Comparison of biofilm development on three building and restoration stones used in French monuments. International Biodeterioration \& Biodegradation, 2021, 165, pp.105322. 10.1016/j.ibiod.2021.105322 . hal-03382328v1

\section{HAL Id: hal-03382328 \\ https://hal.univ-reims.fr/hal-03382328v1}

Submitted on 2 Nov 2021 (v1), last revised 9 Nov 2021 (v2)

HAL is a multi-disciplinary open access archive for the deposit and dissemination of scientific research documents, whether they are published or not. The documents may come from teaching and research institutions in France or abroad, or from public or private research centers.
L'archive ouverte pluridisciplinaire HAL, est destinée au dépôt et à la diffusion de documents scientifiques de niveau recherche, publiés ou non, émanant des établissements d'enseignement et de recherche français ou étrangers, des laboratoires publics ou privés. 


\title{
COMPARISON OF BIOFILM DEVELOPMENT ON THREE BUILDING AND RESTORATION STONES USED IN FRENCH MONUMENTS
}

\author{
Stéphanie Eyssautier-Chuine ${ }^{\mathrm{a}}{ }^{*}$, Nathalie Vaillant-Gaveau $^{\mathrm{b}}$, Emilie Charpentier $^{\mathrm{c}}$, Fany Reffuveille $^{\mathrm{c}}$
}

a Groupe d'Étude sur les Géomatériaux et les Environnements Naturels Anthropiques et Archéologiques EA 3795 (GEGENAA) - SFR Condorcet FR CNRS 3417 - 2, Esplanade Roland Garros, Université de Reims Champagne-Ardenne (URCA), 51100 cedex, Reims, France.

${ }^{*}$ Correponding author: stephanie.eyssautier@univ-reims.fr

${ }^{\mathrm{b}}$ Unité de Recherche EA 4707 Résistance Induite et Bioprotection des Plantes (RIBP), SFR Condorcet FR CNRS 3417, UFR Sciences Exactes et Naturelles, Université de Reims Champagne-Ardenne, Reims, France. nathalie.gaveau@univ-reims.fr

${ }^{\mathrm{c}}$ Biomatériaux et Inflammation en Site Osseux EA 4691 (BIOS), U.F.R. Pharmacie, 51, rue Cognacq Jay, Université de Reims Champagne-Ardenne (URCA), 51095 Reims Cedex, France. fany.reffuveille@univ-reims.fr

\begin{abstract}
This study investigated the bioreceptivity of two Lutetian limestones (Courville and Ditrupa), mainly used in the north-eastern region of France, and of their restoration stone (Savonnieres). Samples of the three stones were exposed outdoor for 2.5 years to determine if the replacement of Lutetian stones by Savonnieres was relevant regarding their intrinsic properties and their susceptibility to microbial colonisation. Cultivation assays revealed the presence of similar strains for all stones, but the number of bacteria changed and reached 703.5 CFU/ $\mathrm{cm}^{2}$ for Courville, $964.5 \mathrm{CFU} / \mathrm{cm}^{2}$ for Ditrupa and 254.8 $\mathrm{CFU} / \mathrm{cm}^{2}$ for Savonnieres. A significant colour change of the surfaces was noticed during the first winter, especially for Savonnieres $\left(\Delta \mathrm{E}^{*} \mathrm{ab}=18.3\right)$. It was associated with a net increase of the chl. $a$ fluorescence and of the pigment content, which suggested a clear growth of phototrophic microorganisms. The Hg porosimetry showed that the porous network of Courville was only slightly impacted by biocolonisation, in contrast to Ditrupa and Savonnieres, where the macropores were obstructed. Savonnieres stone had a weaker bioreceptivity for bacteria than Lutetian stones, but it strongly promoted the colonisation by other microorganisms which could induce more severe bioweathering than on the Lutetian stones.
\end{abstract}

\section{Highlights:}

- The bioreceptivity of two Lutetian limestones and of their restoration stone was compared.

- Lutetian stones showed high bacterial growth but a low phototrophic development.

- The replacement stone developed weak bacterial growth but the highest biocolonisation by photosynthetic microorganisms.

- The microporosity of stones seemed to promote bacterial growth, whereas in the macropores, phototrophs developed.

\section{Keywords:}

Stone monuments, bioreceptivity, bacteria, phototrophs, porosity. 


\section{Introduction}

The selection of a stone to erect prestigious buildings and religious edifices has always been conducted by an aesthetic criterion, the availability of the material and its physical characteristics to support mechanical stresses (Přikryl and Török, 2010). Basements were often built in hard stones to limit water infiltration, whereas frameworks and sculptures were made in soft stones (Siegesmund and Török, 2014). The conservation of cultural heritage $(\mathrm{CH})$ consists of keeping intact objects and buildings over time, which has always been a real challenge particularly for outdoor $\mathrm{CH}$, where the degradation of natural materials depends on the climatic conditions and human activity. In a monument, all stones are not subjected to the same weathering processes because of their intrinsic properties (mineralogical and chemical composition, petrophysical and mechanical properties) and their position in a monument (Bellopede et al., 2016; Gulotta and Toniolo, 2019).

In the northern part of France, the temperate climate strongly influences stone weathering, with temperature and humidity variations especially in the areas located in the Paris Basin since limestones are major building stones and are highly sensitive to weathering (Durnan, 2015). Lutetian limestones belong to a geological stage of the same name and spread over a large area from the west in the Normandy to the east in the Champagne region. They were used from antiquity in most of the buildings and monuments in Paris and its surroundings, but they display important horizontal and vertical sedimentary variability that changes their composition and their intrinsic properties (Fronteau et al., 2010). In Rheims and throughout the Champagne region, situated in the eastern part of France, Lutetian limestones represented several local stones which built many houses, churches and monuments from the $\mathrm{XII}^{\text {th }}$ to the $\mathrm{XX}^{\mathrm{h}}$ century. They were the dominant materials in the XVII ${ }^{\text {th }}$, and its use decreased in the XVIII ${ }^{\text {th }}$ century. Two Lutetian limestones, called Courville and Ditrupa stones, are employed in all positions of buildings, mostly in wall elevation, frames and sculptures, secondary in the basement for Courville stone (Turmel, 2014). Another stone, Savonnieres stone, which is not local, became one of the main building stones of the XVII ${ }^{\text {th }}$ and XVIII ${ }^{\text {th }}$ centuries in restoration to replace Lutetian limestones in window frames, pinnacles and sculptures. This stone is still mined, whereas Lutetian limestone quarries are presently closed. The Notre Dame Gothic Cathedral in Rheims, one of the most prestigious monuments in France, illustrates the use of many Lutetian limestones, in particular those three limestones used in similar parts of the monument because of their close visual appearance (Turmel et al., 2014). Nonetheless, one of the first actions of the climate and other external factors, such as pollution, is to impact aesthetics by weathering, depending on the stone properties and its position in the monument. Therefore, the choice of restoration stones is crucial. Studies of Lutetian stones and Savonnieres on site highlighted different decay patterns, such as thin layers of desquamation for Lutetian stones and a sandy homogeneous disintegration of the surface for Savonnieres stone (Fronteau et al., 1999). An acidic atmosphere caused a yellowing of stones by the reaction of sulphuric acid with calcite of the stones (Gibeaux et al., 2018). A recent laboratory study on Courville and Savonnieres stones displayed a higher sensitivity to frost and salt weathering damage for Courville stone (Huby et al., 2020). However, biological weathering has not been studied yet, despite a visual biocolonisation of those stones in monuments (Fig. 1). Biocolonisation, defined as "any undesirable change in a material brought by vital activities of organisms" (Hueck, 2001), is considered as an unsightly soiling of cultural heritage artefacts in stone, but it can also lead to irremediable historical and cultural losses in the long term. The bacterial diversity of a Lutetian limestone in the Chaalis abbey in the north-western region of France has already been analysed (Mihajlovski et al., 2017), but the composition and the petrophysical properties of this stone differ to those of Courville and Ditrupa stones (Vázquez et al., 2016), which can induce a different biocolonisation.

In that respect, this study investigated and compared the progressive biocolonisation of the two Lutetian limestones (Courville and Ditrupa stones) and their restoration stone (Savonnieres stone) through an outdoor test over a period of 2.5 years. The aim was to discern if Savonnieres stone was a judicious choice as a restoration stone regarding the bioreceptivity of the three stones. Sound and sterile samples were exposed at the same time and in the same position to the same environmental and 
climatic conditions. In the field, biocolonisation was monitored monthly by colorimetry and the development of phototrophic organisms by chlorophyll $a$ fluorescence. In the laboratory, chlorophyll $a$ estimation supplemented the in-situ data, and the bacterial colonisation was analysed by agar culture for identification and quantification. Petrophysical analyses and microscopic observations of colonised stones were carried out to better understand the involvement of the intrinsic properties of the three stones on their bioreceptivity.

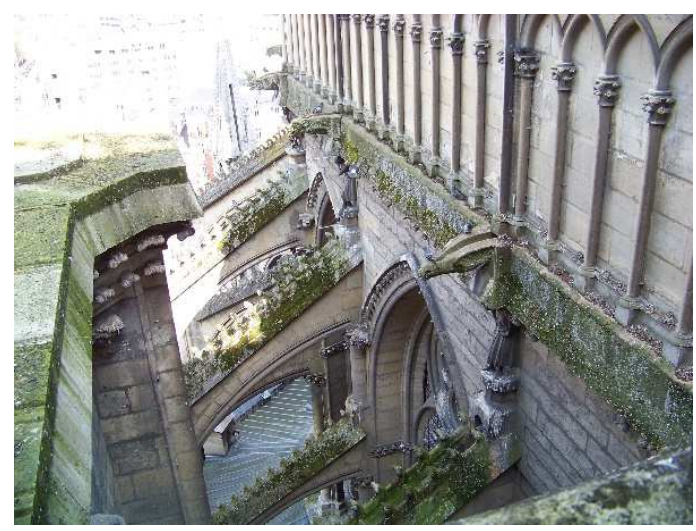

Fig. 1: Photo of the Rheims cathedral apse made of the Courville and Ditrupa stones in wall elevations and Savonnieres stone in caps and decorations of buttresses (photo: G. Fronteau 2008).

\section{Materials and methods}

\subsection{Presentation of the studied stones}

Courville stone dating back to the Lutetian stage (41-47.8 My) belongs to the Lutetian limestones of the Paris Basin. The term Lutetian refers to Lutetia, the name given to Paris during Antiquity. It is a common stone in Parisian buildings, obtained from quarries located in the underground of the capital. Lutetian limestones provided prestigious ashlars from Antiquity and were also employed in many buildings and Gothic cathedrals around Paris (Fronteau et al., 2010). Courville stone is one of the main building stones of Rheims City and the surroundings. The quarries are located in the western part of the city and are closed now. It is a clear yellow limestone, classified as a packstone, with a micritic matrix and coarse white shells and micro-fossils, namely foraminifera (milliolids, Orbitolites complanatus) and calcareous algae (Dasycladaceae) (Fig. 2). Nonetheless, the Lutetian sedimentary sequence in the Paris Basin has important vertical, lateral and geographical variations, which generated variations of the petrography (composition of stones) and of the petrophysical properties of Lutetian stones (Fronteau et al., 2010). Ditrupa stone testifies to this variability. It also belongs to the Lutetian limestones from quarries in the surroundings of Rheims and was frequently used as Courville stone in many buildings and monuments of this region. It is a clear, whitish coloured stone, classified as a packstone, with a micritic matrix and fossils (bivalves, gastropods and echinoderm ossicles), as well as micro-fossils such as milliolids. This stone is characterised by Ditrupa strangulata tubes made of polychaete worms (annelids).

The Savonnieres stone is a limestone dating back to the Lower Tithonian (150 My) and still mined in the two last quarries in the vicinity of Saint Dizier City in Eastern France. It appeared in buildings from the modern period (1755) in Rheims City and is now employed for restoration (Fronteau et al., 2014). It is a clear limestone classified as a grainstone, with calcite spar crystals which surround oolit vacuolar grains and shell debris (Fig. 2). The composition is highly different to that of the two Lutetian limestone ones since the texture is grain-supported, with numerous large elements. 


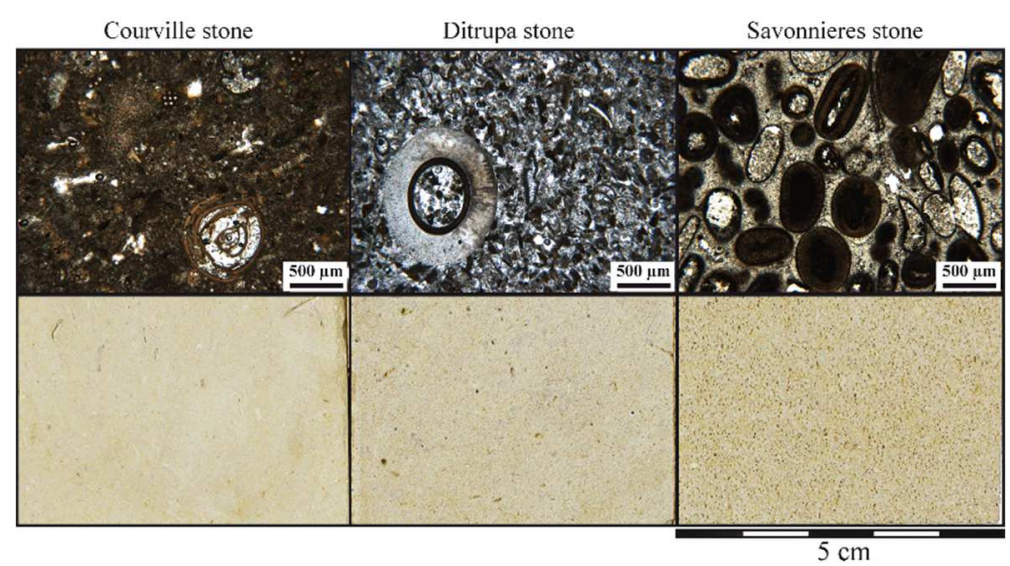

Fig. 2: Photos in microscopy (thin section in polarized light) and macroscopy of Courville (a), Ditrupa (b) and Savonnieres stone (c).

\subsection{Biofouling test}

This test consisted of a natural biocolonisation of stone samples to study the micro-organisms developed over 2.5 years (from October 2016 to April 2019) (Fig. 3). The climate is temperate, with wet and cold winters and warm to hot summers. During the test period, these was a rainfall average of $43 \mathrm{~mm}$, with a minimum in April 2017 of $10.2 \mathrm{~mm}$ and a maximum in September of the same year of $109 \mathrm{~mm}$. The average of temperature went from $1.9^{\circ} \mathrm{C}$ in February 2017 to $21.7^{\circ} \mathrm{C}$ in July 2018 , but during a short period, negative temperatures were reached in the winter and spring of 2017, 2018 and 2019 (-11.6 and $-11.1^{\circ} \mathrm{C}$ in February 2017 and 2018, $-3.9^{\circ} \mathrm{C}$ in April 2019). During the summer, the maximum temperatures reached $35^{\circ} \mathrm{C}$ in June 2017 and $36.9^{\circ} \mathrm{C}$ in July 2018 (Table S1).

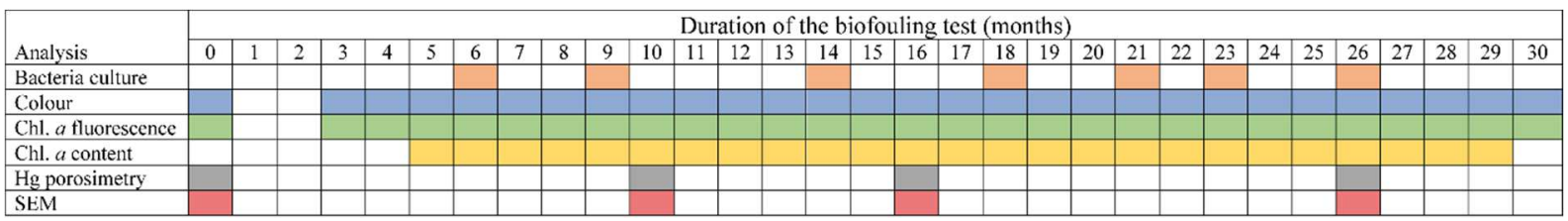

Fig.3: Gantt chart which maps out the time schedule of field measurements and of sampling for laboratory analyses.

Samples were settled on a galvanised steel platform $1 \mathrm{~m}$ above the ground and $20^{\circ}$ tilted to the $\mathrm{SW}$ to limit the stagnation of water and maximise sunshine (Fig. S1). Located outdoor in the garden of Sacré Coeur secondary school in Rheims City, they were previously sterilised to kill bacteria already occurring on the stone surface to start new natural seeding. In total, 230 small samples per limestone (dimensions: $2 \times 2 \times 1 \mathrm{~cm}$ ) were exposed for the laboratory analysis (quantification of cultivable bacteria and of chlorophyll $a$ ), and four larger samples per limestone (dimensions: $10 \times 10 \times 5 \mathrm{~cm}$ ) were settled for in-situ measurements each month for colour and chlorophyll $a$ fluorescence. Small dimensions for samples were preferably used to frequently collect triplicates for the destructive analyses, whereas larger samples were settled to obtain a larger and identical surface of measurement throughout the test period. This dimension ensured the stability of the samples for a better weather resistance.

\subsection{Field study}

\subsubsection{Colourimetry}

Surface colourimetry is often used as a non-destructive technique to monitor the changes in stone colour on monuments due to the fouling induced by microbial growth (Grossi et al., 2007; Cutler et al., 2013; Vázquez-Nion et al., 2013; Pozo-Antonio et al., 2017).

Stone colour was measured using a Chroma Meter CR-400 by Konica-Minolta, equipped with a light projection tube CR-A33c of $11 \mathrm{~mm}$ in diameter, which is the measurement zone. Calibrations were done with a white ceramic plate CR-A43, and values are given in the CIELAB colour space (European 
Committee for Standardization EN ISO 11664-4 and CIE Technical Report 2004). Three parameters define the colour location in colour space: $\mathrm{L}^{*}$ is the lightness $(0=$ absolute black, $100=$ absolute white); $a^{*}$ and $b^{*}$ are the chromaticity coordinates; $a^{*}$ is the position between green $\left(a^{*}<0\right)$ and red/magenta $\left(a^{*}>0\right) ; b^{*}$ is the position between blue $\left(b^{*}<0\right)$ and yellow $\left(b^{*}>0\right)$.

The measurements were carried out from the month 3 (January 2017) to month 30 (April 2019). A grid of the size of the samples $(10 \times 10 \times 5 \mathrm{~cm})$ with 25 regular spaces was placed on the top surface of each sample to position the device and to take 25 measurements each month. Colour was measured at the beginning of the test (T0 in October 2016) and then once each month from month 3 (considering that no changes in biological colonisation occurred during the first 3 months) to month 30 . The CIELAB lightness and chroma differences were calculated as follows: $\Delta \mathrm{E}_{\text {ab }}^{*}$ (global colour variation), $\Delta \mathrm{L}^{*}, \Delta \mathrm{a}^{*}, \Delta \mathrm{b}^{*}$ as the difference between the values at each stage of the test and the first values measured at $\mathrm{T} 0 ; \Delta \mathrm{E}^{*}$ ab was calculated from the three colour parameters using Equation (1). An average of the colour parameters was established for each type of stone from the four samples of the same stone.

$$
\Delta \mathrm{E}_{\mathrm{ab}}^{*}=\sqrt{\Delta L^{* 2}+\Delta a^{*^{2}}+\Delta b^{*^{2}}}
$$

\subsubsection{Chlorophyll $a$ fluorescence}

In cultural heritage, this non-invasive technique has already been carried out in situ and over a long term to investigate the physiological adaptation of lichens to changes in microclimatic conditions (Baruffo and Tretiach, 2007) and the effects of biocides (Pfendler et al., 2018; Bruno et al., 2019). The fluorescence from chlorophyll $a$ is almost exclusively from photosystem II (PSII) in the photosynthetic chain of plants. In-situ measurements were first carried out at month 3 (considering that growth of phototrophic microorganisms has not be detected before) and then once a month for 2.5 years. A handheld photosynthesis yield analyser, Junior PAM Chlorophyll Fluorometer (Walz, Effeltrich, Germany), was coupled to the WinControl-3 Software. The device operated with the pulseamplitude modulated (PAM) in combination with saturating pulse analysis of fluorescence quenching. The same grid for colour measurements was also used to perform 25 fluorescence measurements onto the whole top surface of each sample of with a dimension of $10 \times 10 \times 5 \mathrm{~cm}$ via a visible blue power LED $(460 \mathrm{~nm})$ for modulated and saturating pulses. The light released was $190 \mu$ mol photons. $\mathrm{m}^{-2} . \mathrm{s}^{-1}$ of PAR (photosynthetic active radiation), with the fibre-optic probe of the fluorometer applied to the sample. For each measurement, the probe was moved in a grid space, and two parameters were recorded: the minimal fluorescence of light-adapted biofilm $\left(\mathrm{F}_{0}^{\prime}\right)$ and the maximal fluorescence during the saturating light $\left(\mathrm{F}_{\mathrm{m}}\right)$. From those parameters, the relative quantum yield of PSII, $\phi$ PSII, was calculated using the equation $\mathrm{F}^{\prime}{ }_{\mathrm{V}} / \mathrm{F}_{\mathrm{M}}{ }_{\mathrm{M}}=\left(\mathrm{F}_{\mathrm{M}}{ }_{\mathrm{M}}-\mathrm{F}_{0}\right) / \mathrm{F}_{\mathrm{M}}{ }_{\mathrm{M}}$. Measurements were carried out without preliminary darkness and wetness phases, and therefore, $\varphi$ PSII reflects the real photosynthetic yield of microorganisms in natural conditions.

\subsection{Laboratory study}

\subsubsection{Bacterial strain quantification}

Small samples $(2 \times 2 \times 1 \mathrm{~cm})$ were collected in triplicate for each type of stone and for each time period (months $6,9,14,18,21,23$ and 26). The quantity of live and cultivable adhered bacteria was evaluated following bacteria detachment by ultrasound. Samples were washed in PBS (phosphate buffered saline) and transferred to a tube containing $8 \mathrm{~mL}$ of this solution. Bacteria were then detached by exposing the sample to $5 \mathrm{~min}$ of ultrasound ( $40 \mathrm{kHz}$ ) (Reffuveille et al., 2018). A volume of $100 \mu \mathrm{L}$ from serial dilutions was plated on nutrient agar plates to grow bacteria. The same protocol was performed with non-exposed and sterile triplicates of each type of stone, which were used as negative controls. Isolates were quantified via a visual counting of the colonies according to morphotypes (colour and aspect).

\subsubsection{Identification and phylogenetic analysis of bacterial strains}

A microbial suspension from each isolate of the bacterial culture described previously was prepared by mixing a colony with $100 \mu \mathrm{l}$ of Milli-Q water. It was then placed into a water bath for 5 min at $95^{\circ} \mathrm{C}$, 
followed by $-80^{\circ} \mathrm{C}$ for 1 hour (five cycles) to break the microbial cells and have access to the genomic DNA. The DNA was used as a template for $16 \mathrm{~S}$ rRNA amplification by PCR with primers $8 \mathrm{~F}$ (5'AGAGTTTGATCCTGGCTCAG-3') and 1391R (5'- GACGGGCGGTGTGTRCA-3') (Sim et al., 2012). The PCR product was then sent to Genoscreen (France) for primer removal and for further sequencing using an automatic DNA sequencer (model 3730xl; Applied Biosystems). The sequences were then blasted online (https://blast.ncbi.nlm.nih.gov/Blast.cgi) and aligned with the closest relative sequences of representatives (determined by the BLASTN), using the CLUSTALW program (Thompson et al., 2002). The partial sequences of the 16S rRNA gene represented a sequence of with a length of 765 nucleotides, which was aligned on a total of 1,268 unambiguous position based on the E. coli numbering system.

\subsubsection{SEM observations during biocolonisation}

Environmental SEM was used to observe the biofilm on the stone surface at months 10, 16 and 26. The apparatus was a SEM Hitachi TM-3030 plus Tabletop Microscope. Samples introduced in the microscope had a dimension of $2 \times 2 \times 0.5 \mathrm{~cm}$ and were placed on a double-sided adhesive carbon tape; the accelerating voltage was $15 \mathrm{kV}$ for imaging, with a working distance of $6 \mathrm{~mm}$. All images were acquired in the back-scattered electron mode.

\subsubsection{Chlorophyll $a$ estimation by spectrophotometry analysis}

Quantification of chl. $a$ was carried out at months 5 and 7, then monthly from month 9 to month 21, by collecting triplicates (of $2 \times 2 \times 0.5 \mathrm{~cm}$ dimension) of each stone type. Samples were cut and ground, and the chlorophyll was extracted with $95 \%$ ethanol $(50 \mathrm{ml})$ at $70^{\circ} \mathrm{C}$ for 3 hours. After overnight incubation at $4{ }^{\circ} \mathrm{C}$, the chlorophyll concentration was estimated from the supernatant by measuring absorbance at $665 \mathrm{~nm}$ wavelength after centrifugation (spectrophotometer Thermo Fisher Scientific Genesys 10-S). The chl. $a$ content was calculated using a conversion factor $\left(72.3 \mathrm{mg} \mathrm{chl} . \mathrm{ml}^{-1}\right)$, as described in the formula (2) (Malam Issa, 1999): (OD 665 is the optical density at $665 \mathrm{~nm}$ )

$$
\text { Chl. } a=\frac{\text { OD } 665}{72.3}
$$

\subsubsection{Porosity and pore access radii}

The microstructural characteristics of stones were assessed through the mercury $(\mathrm{Hg})$ intrusion measurements to evaluate the modification of the porous network involved by the biofilm on the stone surface. One sample of stone $(1 \times 1 \times 1 \mathrm{~cm})$ was analysed prior to exposure, and the data were used as standard. Samples were collected from the outdoor test at months 10, 16 and 26 of exposure. The upper face of the stone was sawn $(0.5 \times 1 \times 1 \mathrm{~cm})$, and $\mathrm{Hg}$ porosity and pore size distribution were measured with a mercury intrusion porosimeter (Micromeritics Autopore IV 9500), reaching a pressure of $247 \mathrm{MPa}$ and measuring pore radii sizes from 0.003 to $178 \mu \mathrm{m}$.

\section{Results}

\subsection{Characterisation of the porous network of stones}

The intrinsic properties of the stones were analysed with petrographic observations and petrophysical measurements: water total porosity, capillary coefficient according to standards (European committee for Standardization, 2007; European Committee for Standardization, 2010) and drying kinetics from the water evaporation test (Rousset-Tournier et al., 2003). Furthermore, mercury porosity and the pore access radius distribution of stones were measured with a Micromeritics AutoPore IV 9500 (Table 1). Courville stone has a water total porosity at $23.4 \%$; the pore distribution is unimodal with one main pore access radius at $0.1 \mu \mathrm{m}$, making it a microporous stone. The capillarity coefficient is $45.7 \mathrm{~g} \cdot \mathrm{m}^{-2} \cdot \mathrm{s}^{-}$ ${ }^{1 / 2}$, displaying a medium capillary transfer kinetics and a high water saturation (84.4\%). The drying kinetics, induced from the water evaporation test, achieved a critical saturation (Sc) at 50.0\%, meaning that $50 \%$ of the water is evaporated from the surface by capillarity in 55.8 hours $\left(\mathrm{T}_{\mathrm{Sc}}\right)$. 
Ditrupa stone has a water total porosity at $14.8 \%$ and is related to a mouldic porosity located in dissolved fossils and to an intergranular porosity in a matrix partially recrystallised. The pore distribution is bimodal, with two main pore access radii: between 3 and $8 \mu \mathrm{m}$ and at $0.08 \mu \mathrm{m}$. This stone is characterised by a weak capillary coefficient $\left(10.2 \mathrm{~g} \cdot \mathrm{m}^{-2} \cdot \mathrm{s}^{-1 / 2}\right)$ and a weak saturation $(30.0 \%)$; thus the pore network is much less connected than that of Courville stone. Nonetheless, the drying kinetics is similar, with a critical saturation $(\mathrm{Sc})$ at $49 \%$ and a $\mathrm{T}_{\mathrm{Sc}}$ at 45.4 hours despite a standard deviation of 14.2 which suggests a higher data variability and thus a heterogeneity of the porous network. Although both Lutetian stones have the same geographical origin, the characteristics of the porous network vary due to differences in the textural composition. However, they are closer than Lutetian limestone from the north west of Paris which is more porous (40\%) with a large pore radius $(16 \mu \mathrm{m})$ and a high capillary coefficient $\left(1215 \mathrm{~g} \cdot \mathrm{m}^{-2} \cdot \mathrm{s}^{-1 / 2}\right)$ (Vázquez et al., 2016).

Savonnieres stone has a higher water total porosity, reaching 33.9\%. It is composed of intragranular moulding macropores by dissolution of oolit nuclei (Fig.2) and is weakly connected (Fronteau, 2000; Roels et al., 2000), whereas a second macroporosity is intergranular due to the partial cementation between oolits and is considerably more connected. Finally, a microporosity is located inside the oolit fringes and in nuclei, when still existing. The connected porous network describes a bimodal pore distribution with main pore access radii at $8-10 \mu \mathrm{m}$ and $0.1 \mu \mathrm{m}$ (Table 1). Moreover, Savonnieres has fast capillary transfer kinetics with a capillary coefficient of $111.0 \mathrm{~g} . \mathrm{m}^{-2} \cdot \mathrm{s}^{-1 / 2}$; the drying kinetics displays a weak critical saturation (27\%) and a slow drying (98.4 hours), but it does not take into account the fact that numerous oolitic macropores at the surface dry quickly since they are weakly connected with the network.

Accordingly, both Lutetian stones have different texture and petrophysical characteristics. Ditrupa stone has two main pore sizes, with a large pore access radius of $3 \mu \mathrm{m}$, whereas Courville stone has a unimodal distribution and microporosity. Despite the presence of large pores, porosity, water absorption and saturation are lower than in Courville stone, which reveals a lower connectivity of the porous network. Savonnieres stone, employed as a replacement for Lutetian stones, has a much higher porosity and capillary, suggesting a good connectivity of the network, saturation is lower than in Courville. In addition, the drying kinetics indicates that Savonnieres stone releases less water and over a longer period than Lutetian stones.

\begin{tabular}{lcll}
\hline Stone name & Courville & Ditrupa & Savonnieres \\
\hline Classification (Dunham) & Packstone & Packstone & Grainstone \\
Water total porosity (\%) & $23.4 \pm 1.5$ & $14.8 \pm 5.1$ & $33.9 \pm 1.1$ \\
Capillary coefficient: & & & \\
$\mathrm{C}_{1}\left({\mathrm{~g} . \mathrm{m}^{-2} .}^{-1 / 2}\right)$ & $45.7 \pm 11.4$ & $10.2 \pm 5.7$ & $111.0 \pm 15.3$ \\
Saturation (\%) & $84.4 \pm 0.7$ & $30.0 \pm 6.8$ & $50.2 \pm 0.8$ \\
Drying kinetics at 33\%: & & & \\
Critical saturation Sc $(\%)$ & $50.0 \pm 0.4$ & $49.0 \pm 4.3$ & $27.0 \pm 1.2$ \\
Critical saturation time $\mathrm{T}_{\mathrm{Sc}}(\mathrm{h})$ & $55.8 \pm 0.2$ & $45.4 \pm 14.2$ & $98.4 \pm 3.3$ \\
Pore radii thresholds $(\mu \mathrm{m})$ & 0.1 & $3-8 ; 0.08$ & $8-10 ; 0.1$ \\
Pores $(\%): \quad>10 \mu \mathrm{m}$ & $4.0 \pm 1.2$ & $12.2 \pm 4.6$ & $17.1 \pm 2.7$ \\
$\quad 10-1 \mu \mathrm{m}$ & $1.9 \pm 1.6$ & $28.3 \pm 3.0$ & $37.1 \pm 0.8$ \\
$1-0.1 \mu \mathrm{m}$ & $30.0 \pm 3.6$ & $38.7 \pm 4.2$ & $33.4 \pm 2.5$ \\
$\quad<0.1 \mu \mathrm{m}$ & $64.1 \pm 6.3$ & $20.7 \pm 3.1$ & $12.4 \pm 0.8$ \\
\hline
\end{tabular}

Table 1: Petrophysical characteristics of Courville, Ditrupa and Savonnieres stones.

\subsection{Identification and quantification of bacterial colonies}

Bacterial colonies have been identified and counted from morphotypes grown and isolated on agar plates. The microbial culture showed that the same strains developed on the three types of stones. Major colonies were identified (Table 2). The phylotype Actinobacteria was strongly represented by red and pink bacteria belonging to Arthobacter sp. and Rhodococcus sp., Microbacterium phyllosphaerae. The second phylotype was bacilli with Bacillus safensis and Bacillus subtilis. The last 
phylotype belonged to Gammaproteobacteria represented by Stenophomonas sp. The nucleotide sequence data reported in this paper were deposited in the NCBI nucleotide sequence database under accession numbers MW999226 - MW999340 - MW999341 - MW999348 - MW999925 - MW999351 - MW999406 - MW999410 - MW999411 - MW999413 - MW999414 - MW999679.

\begin{tabular}{|l|l|l|l|}
\hline Phylogenetic closest affiliation of isolates & Color & Similarity $(\%)$ & Accession number* \\
\hline Rhodococcus cerastii strain T9.1 & Orange & $99.1 \%$ & MN198046.1 \\
\hline Rhodococcus fascians A25f & Orange & $99.8 \%$ & CP049744.1 \\
\hline Rhodococcus sp. D2 & Orange & $100 \%$ & AY953293.1 \\
\hline Arthrobacter agilis strain GS52 & Red & $100 \%$ & MT397170.1 \\
\hline Arthrobacter sp. strain CP30 & Pink & $97.2 \%$ & MH061260.1 \\
\hline Arthrobacter agilis strain GS51 & Pink & $95.7 \%$ & MT397169.1 \\
\hline Bacillus safensis strain KMF402 & Yellow & $99.8 \%$ & MT642941.1 \\
\hline Bacillus safensis strain MI31 & Beige & $99.4 \%$ & MN117707.1 \\
\hline Bacillus subtilis strain LTNo.1 & Beige-yellow & $99.8 \%$ & MT645308.1 \\
\hline Stenotrophomonas sp. C1BS11_pA & Beige & $100 \%$ & KX023651.1 \\
\hline Stenotrophomonas sp. strain NJ1024 & Beige & $97.0 \%$ & MT362666.1 \\
\hline Microbacterium phyllosphaerae strain P-RA6 & Yellow & $100 \%$ & MT533897.1 \\
\hline
\end{tabular}

Table 2: Closest affiliation of ten isolates. *CR_GenBank accession number.

The number of colonies grown on agar plates (Fig.4 and Table S2a-b-c) displayed the dominance of red Arthrobacter agilis at months 6 and 9 on all stones. Then, there was a diversification of species from month 14 when species sharply grew, especially bacilli. Pink Arthrobacter sp./agilis developed later but became predominant on Courville from month 18, whereas Rhodococcus sp. decreased drastically. On this stone, the number of bacteria increased progressively up to $703.5 \mathrm{CFU} / \mathrm{cm}^{2}$ at the end of the experiment.

On Ditrupa stone, the number of bacteria was lower and more variable over time compared to Courville, except at the end, where Ditrupa was the most colonised of the three stones $(964.5$ $\mathrm{CFU} / \mathrm{cm}^{2}$ ), with pink Arthrobacter sp./agilis and Stenophomonas sp. being the most abundant species. Savonnieres had the lowest number of colonies $\left(254.8 \mathrm{CFU} / \mathrm{cm}^{2}\right.$ throughout the experiment, despite the diversification at month 14, similar to other stones. At month 20, pink and red Arthrobacter sp. were the most abundant species like the other stones $\left(264.0\right.$ and $\left.63.3 \mathrm{CFU} / \mathrm{cm}^{2}\right)$ but at the end of the experiment, at month 26 , the numbers of pink bacteria dropped significantly in favour of the red Arthrobacter agilis and Microbacterium phyllosphaerae.
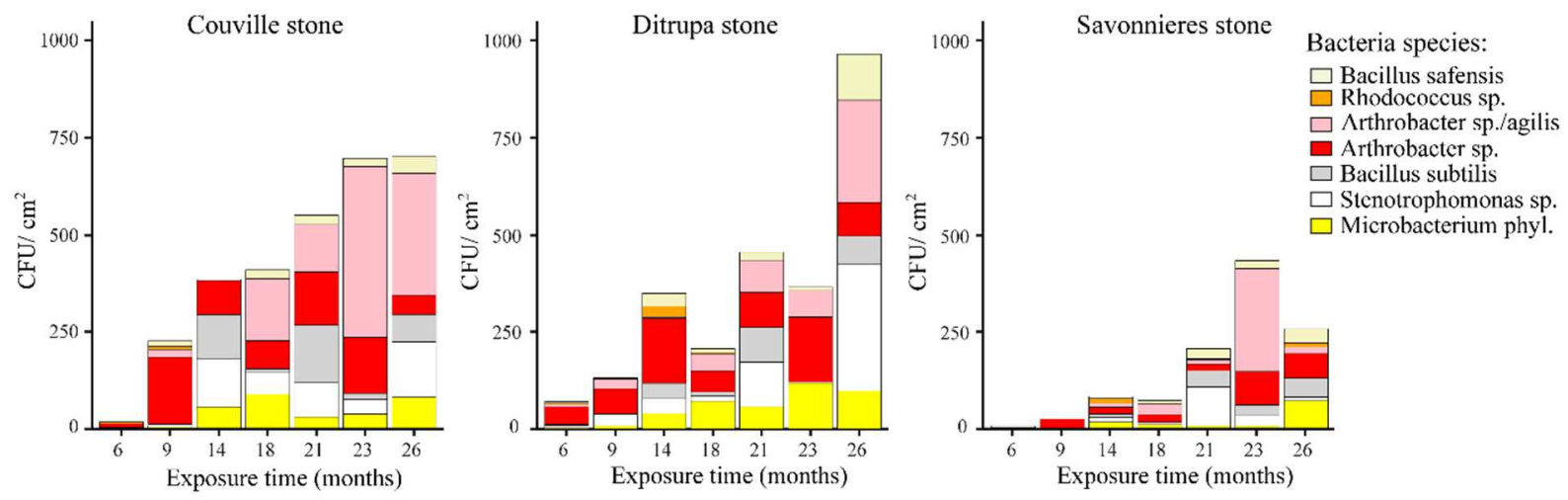

Fig. 4: Number of colonies formed on the stone surface $\left(\mathrm{CFU} / \mathrm{cm}^{2}\right)$ over time for each type of stone from bacterial culture in agar plates.

\subsection{Colour measurements}

Colour measurements were carried out before ageing (T0) and then from month 3 to 30. First, the natural colour of the three stones before exposure was characterised by a high $\mathrm{L}^{*}$ at 76.0 for Ditrupa, 76.6 for Savonnieres and 79.8 for Courville; thus, they all had a clear colour. The values of $b^{*}$ ranged from 11.8 to 13.0 , indicating a yellow colour, whereas $a^{*}$ was less noticeable, with values ranging from 1.7 and 2.9, indicating a slightly to red colour (Table S3). 
The global colour variation $\left(\Delta \mathrm{E}_{\mathrm{ab}}^{*}\right)$ is shown in Figure 5, and its evolution is described hereafter and explained by the other colour parameters: $\Delta \mathrm{L}^{*}, \Delta \mathrm{a}^{*}, \Delta \mathrm{b}^{*}$ (Tables $\mathrm{S} 4, \mathrm{~S} 5, \mathrm{~S} 6$ ). The $\Delta \mathrm{E}_{\text {ab }}^{*}$ was high at the third and fourth month of exposure (Jan. and Feb. 2017), with values between 8.4 and 13.9 for all stones. The global colour changed during the winter, which can be explained by a darkening of stones $\left(\Delta \mathrm{L}^{*}\right.$ was negative, between -11.9 and -4.1$)$ and a yellowing, especially of Courville and Ditrupa with $\Delta \mathrm{b}^{*}$ up to 8.2. This change can be associated to the wetness of stones, induced by regular rainfall and both low insolation and temperatures.

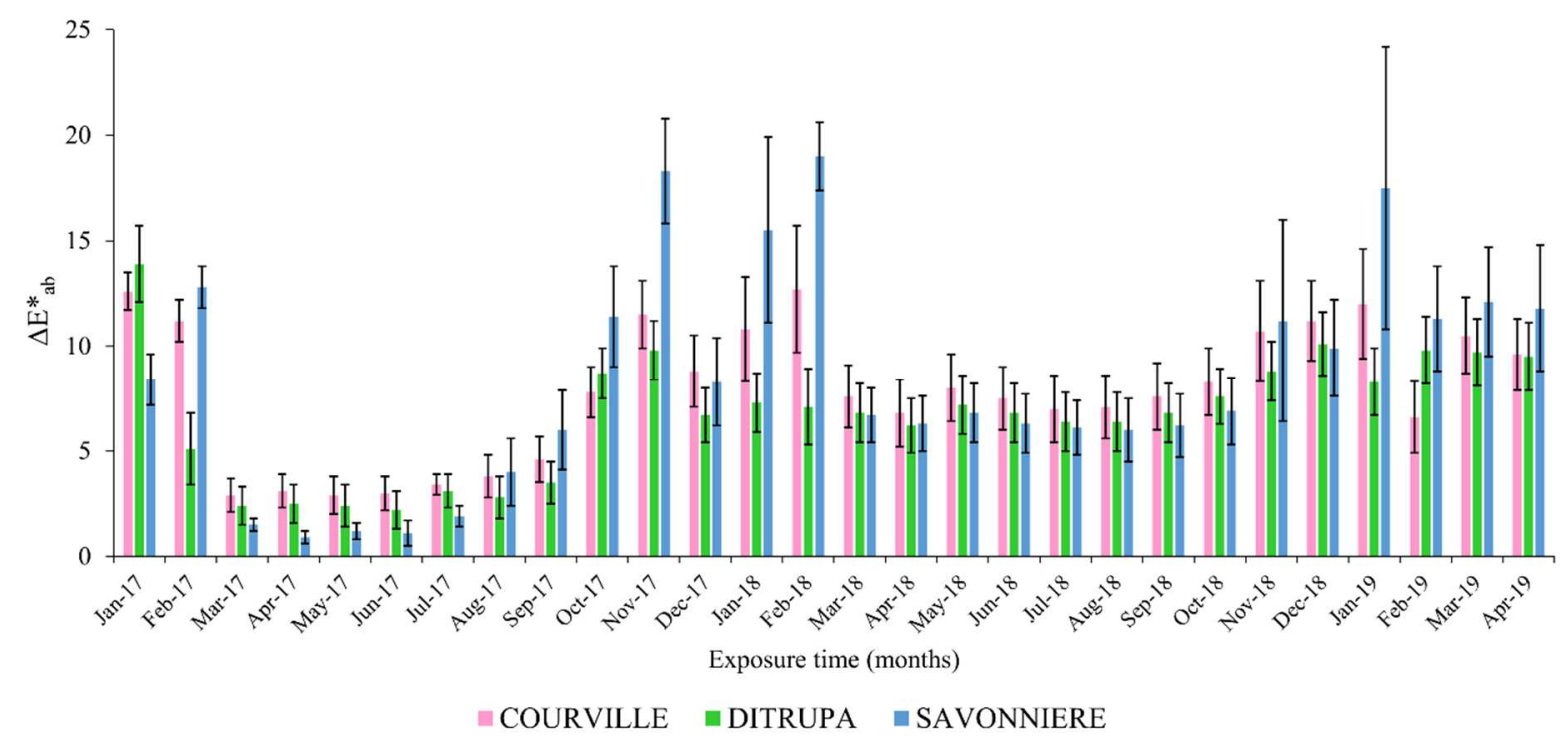

Fig. 5: Global colour variation $\left(\Delta \mathrm{E}_{\mathrm{ab}}\right)$ through the experiment time. $\Delta \mathrm{E}_{\mathrm{ab}}$ has been calculated from the starting of the ageing test in October 2016 (T0) for January 2017 to April 2020.

From March 2017, $\Delta \mathrm{E}_{\text {ab }}^{*}$ dropped to 2.9 for Courville, 2.4 for Ditrupa and 1.5 for Savonnieres. The values remained low throughout spring and summer, until July for Savonnieres and until September for Courville and Ditrupa. This can be11 explained by the drying of stones, which led to a colour close to the initial one. From July for Savonnieres, $\Delta \mathrm{E}^{*}$ ab increased until reaching 18.3 in November, which was the highest colour variation of the three stones. It was characterised by a progressive darkening ( $\Delta \mathrm{L}^{*}$ was from -2.6 to -15.1 ), a greening ( $\Delta \mathrm{a}^{*}$ was from -0.8 to -2.6$)$ and a yellowing of the stone $\left(\Delta \mathrm{b}^{*}\right.$ was from 2.1 to 10.0). On Courville and Ditrupa, the same trend was also observed from September, with a maximum of respectively 11.5 for Courville and 9.8 for Ditrupa, but it was not as high as that for Savonnieres. As a result, biocolonisation was detected by the colour variation in summer on Savonnieres stones and later on, at the beginning of autumn, on the other two stones.

In December 2017, on Savonnieres, $\Delta \mathrm{E}_{\text {ab }}^{*}$ was marked by a rough decrease (8.3), which was explained by a lightening $\left(\Delta \mathrm{L}^{*}=-6.8\right)$, a greening $\left(\Delta \mathrm{a}^{*}=-2.4\right)$ and a bluing of this stone $\left(\Delta \mathrm{b}^{*}=3.8\right)$. Subsequently, $\Delta \mathrm{E}_{\text {ab }}^{*}$ increased in the following 2 months, especially in February with 19.0, with a decrease in $\Delta \mathrm{L}^{*}(-17.8)$. On Courville and Ditrupa, a decrease in $\Delta \mathrm{E}^{*}$ ab was also observed, albeit a lower one (8.8 and 6.7, respectively). Subsequently, it increased for Courville up to12.7, whereas for Ditrupa, the values remained between 6.2 and 7.3 until September 2017.

During the second full year, from March to October 2018, $\Delta \mathrm{E}_{\text {ab }}^{*}$ was stable for all stones, ranging between 6.8 and 8.3 for Courville and 6.0 to 6.9 for Savonnieres. During this period, there was a brightening of all stones, with $\Delta \mathrm{L}^{*}$ levels between -5.8 and -6.8 . The $\Delta \mathrm{a}^{*}$ was slightly negative for Ditrupa (-0.4) and Courville (-0.6) and lower for Savonnieres (-1.2 to -1.5). The $\Delta \mathrm{b}^{*}$ was around 0 for Savonnieres, indicating that the ageing of this stone has not impacted this parameter. On the opposite, Ditrupa and Courville, had $\Delta \mathrm{b}^{*}$ values from 3.5 to 4.2 and from 3.7 to 4.7 , respectively, with a yellowing of both stones.

From November 2017 to January 2018, for Savonnieres, $\Delta E_{a b}^{*}$ increased strongly (from 11.2 to 17.5), which was traduced by a darkening ( $\Delta \mathrm{L}^{*}$ was up to -16.9) and an increase in $\Delta \mathrm{b}^{*}$. Ditrupa and Courville 
colour change increased, but less significantly than that for Savonnieres. Finally, for the last months, $\Delta \mathrm{E}_{\mathrm{ab}}^{*}$ of Savonnieres was around 12, higher than the values for Courville and Ditrupa.

In summary, the natural exposure of stones was characterised by a progressive colour change, in particular a darkening for all stones over time.

The three stones showed the same overall trend, but the trend was stronger for Savonnieres. It was marked by two periods of stability that matched with spring and summer times for both years (2017 and 2018). The first stable one was marked by low colour variations, and the second one had higher $\Delta \mathrm{E}_{\mathrm{ab}}^{*}$ values (between 6.0 and 8.0). Between the stable periods, colour varied strongly during winters, in particular for Savonnieres, characterised by a darkening, a greening and a yellowing of stones. The colour of Savonnieres during exposure showed a different evolution than that for Courville and Ditrupa. The levels of $\Delta \mathrm{a}^{*}$ were always lower, suggesting a higher greening of Savonnieres, notably in winter.

\subsection{Chlorophyll $a$ fluorescence}

Measurements of $\mathrm{F}_{0}$ and $\mathrm{F}_{\mathrm{M}}$ led to the calculation of $\phi \mathrm{PSII}$, which reflects the photosynthetic yield through the occupancy rate of PSII centres. Data followed an overall same trend for the three stones, with values ranging from 0.11 to 0.36 over the 2.5 years (Fig. 6-Table S7). During the first year, $\phi$ PSII increased from January to March and reached a maximum for Ditrupa (0.24); subsequently, the values decreased until July, with 0.09 for Savonnieres and 0.13 and 0.14 for Courville and Ditrupa, respectively. Moreover, this year was highlighted by a strong increase in $\phi$ PSII in November 2017, especially for Savonnieres and Ditrupa stones (0.32 and 0.36, respectively); the levels of $\phi$ PSII decreased during the following 2 months.

In the following year, in spring and summer 2018, the values increased progressively, reaching 0.32 for Ditrupa and 0.29 for Courville in June. The $\phi$ PSII decreased again until December 2018 (0.12 to 0.14). At the beginning of the third year, a new cycle started, and the $\phi$ PSII increased to 0.22 in April 2019.

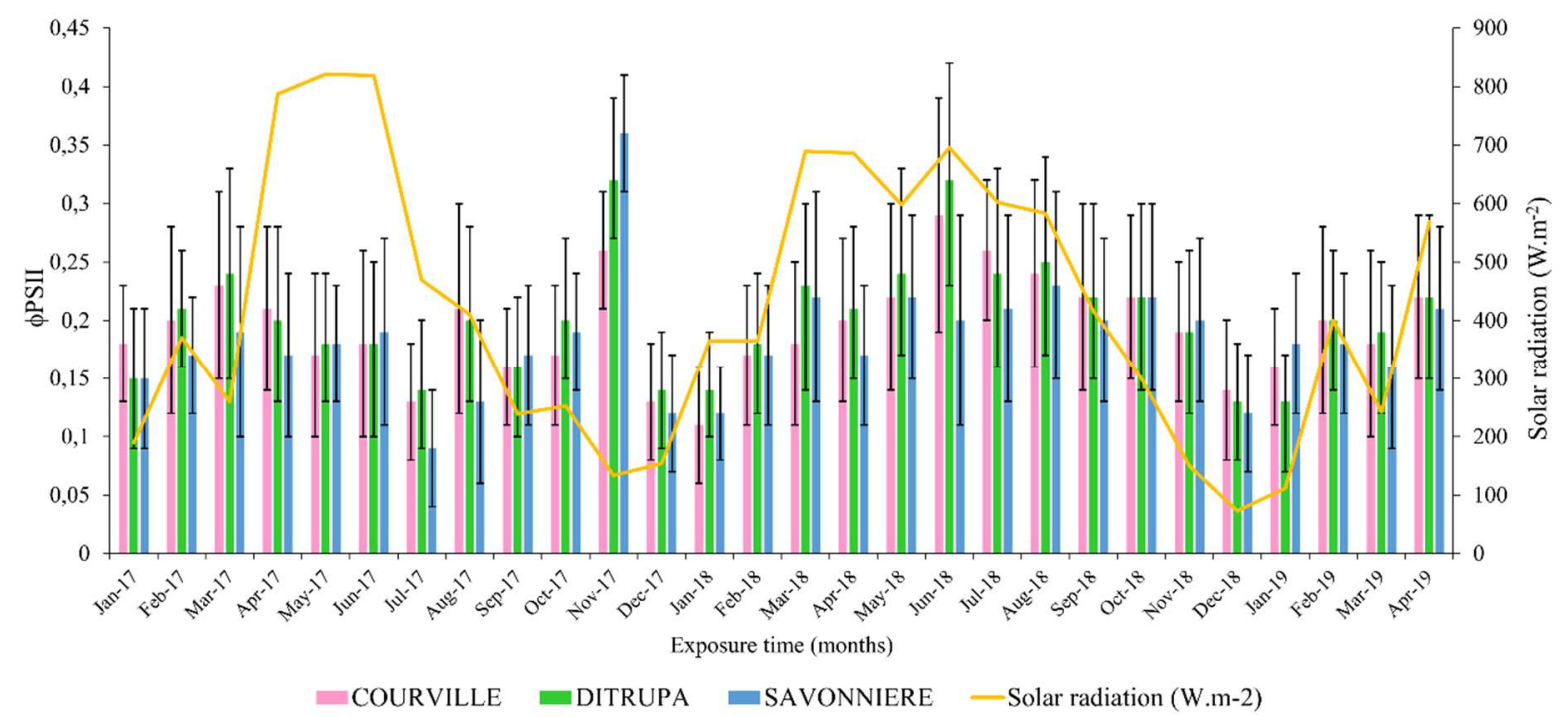

Fig. 6: Chlorophyll- $a$ fluorescence ( $\phi$ PSII) measured from January 2017 to April 2020.

The $\phi$ PSII data were compared to the solar radiation $\left(\mathrm{W} / \mathrm{m}^{2}\right)$, and there was no significant correlation between the two parameters in the first year. The decrease in solar radiation in autumn did not avoid the rapid rise of the photosynthetic activity. Nonetheless, from the second year, $\phi$ PSII was clearly related to solar radiation when the phototrophic microorganisms predominated. 
The $\phi$ PSII decrease during December 2017 and January 2018 seemed to be a result of heavy rainfall ( 88.1 and $83.5 \mathrm{~mm}$, respectively) and negative temperatures (minimum at $-3.1^{\circ} \mathrm{C}$ and $-10^{\circ} \mathrm{C}$ ), most likely causing the death of microorganisms.

\subsection{Chlorophyll $a$ estimation}

The Chlorophyll $a$ (Chl. $a$ ) content was close to 0 from March to September 2017 for Courville (Fig. 7 - Table S8). It was quantified from July (month 8) for both Savonnieres $\left(0.49 \mu \mathrm{g} . \mathrm{cm}^{-2}\right)$ and Ditrupa $\left(0.39 \mu \mathrm{g} . \mathrm{cm}^{-2}\right)$. Then, Savonnieres stones always showed a higher Chl. $a$ content than the two others (except in Dec. 2017), which decreased from $1.29 \mu \mathrm{g} . \mathrm{cm}^{-2}$ to $6.01 \mu \mathrm{g} . \mathrm{cm}^{-2}$, whereas Ditrupa's Chl. $a$ content decreased from 0.33 to $3.35 \mu \mathrm{g} . \mathrm{cm}^{-2}$ and Courville's content from 0.35 to $2.38 \mu \mathrm{g} . \mathrm{cm}^{-2}$. There was a first large increase, with a maximum in November 2017, for Savonnieres and Ditrupa, with 3.19 and $1.85 \mu \mathrm{g} . \mathrm{cm}^{-2}$, respectively, and for Courville in December, with $1.60 \mu \mathrm{g} . \mathrm{cm}^{-2}$. The greatest increase occurred the following year at the same months (Nov. to Dec. 2018). Therefore, at the beginning of each winter, the phototrophic microorganisms grew rapidly.

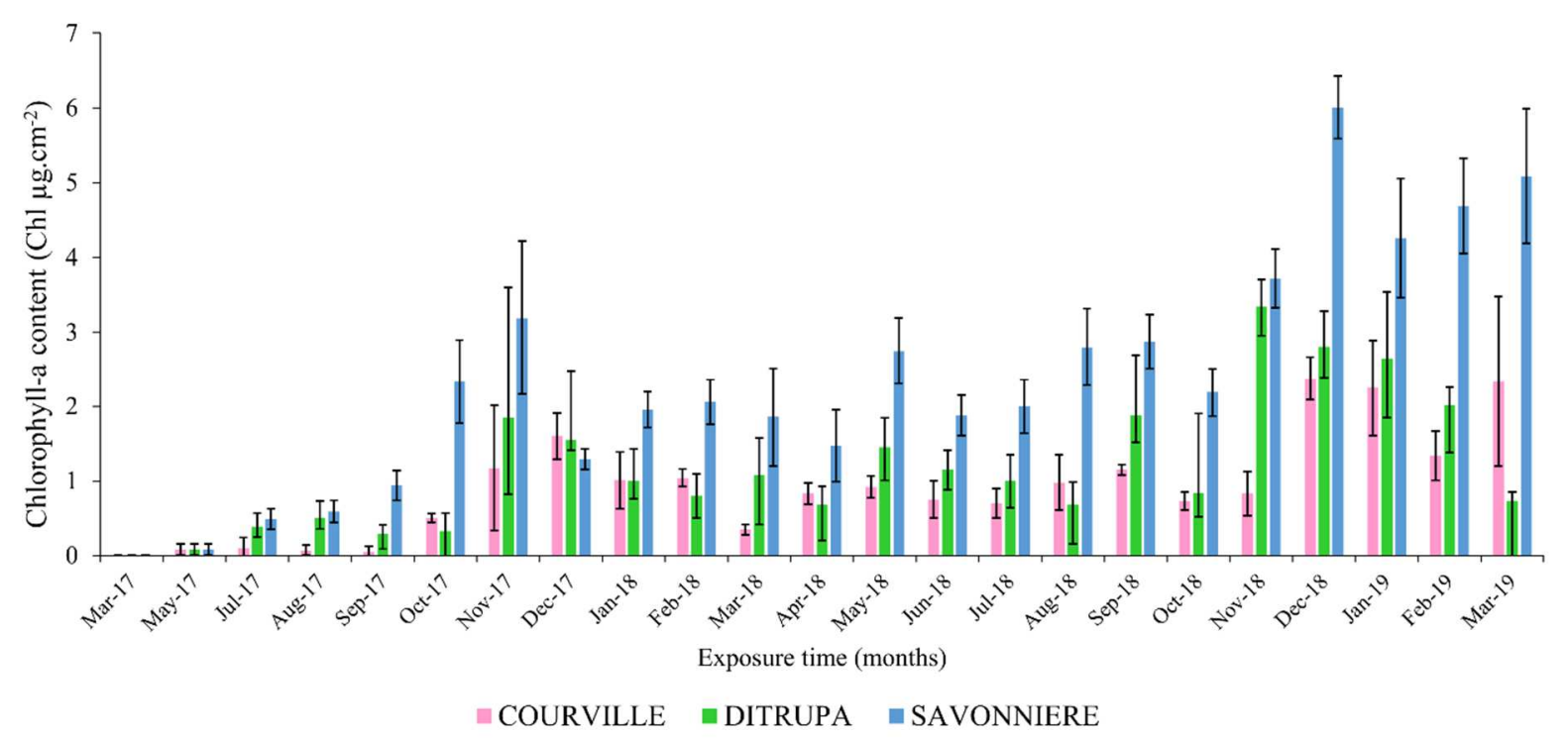

Fig. 7: Chlorophyll- $a$ content $\left(\mu \mathrm{g} . \mathrm{cm}^{-2}\right)$ calculated from spectrophotometry at $665 \mathrm{~nm}$ wavelength.

\subsection{Porous network evolution with biofilm growth}

Stone porosity and pore size distribution were measured via mercury intrusion porosimetry before the experiment (control) and then quantified at three times during the ageing experiment (months 10, 16 and 26). Figure 8 shows a graph for each stone, representing the pore access radius $(\mu \mathrm{m})$ versus the $\mathrm{Hg}$ intrusion $\left(\mathrm{mL} \cdot \mathrm{g}^{-1}\right)$. This is completed by Table S9 with the $\mathrm{Hg}$ porosity $(\%)$ and the $\mathrm{Hg}$ volume $\left(\mathrm{mL} \cdot \mathrm{g}^{-}\right.$ $\left.{ }^{1}\right)$ for four classes of pore access radius.

For Courville stone, the porosity was $25.7 \%$ before the experiment and varied from $23.4 \%$ at month 10 to $22.5 \%$ at month 26 . It was characterised by microporosity, but curves (representing $\mathrm{Hg}$ intrusion as a function of pore access radii) displayed a decrease in pores larger than $10 \mu \mathrm{m}$ from month 10 . Indeed, the $\mathrm{Hg}$ volume was $0.007 \mathrm{~mL} \cdot \mathrm{g}^{-1}$ for the control, $0.003 \mathrm{~mL} \cdot \mathrm{g}^{-1}$ at month 10 and remained low at 16 and 26 months $\left(0.004\right.$ and $0.002 \mathrm{~mL}^{-1} \mathrm{~g}^{-1}$. Moreover, there was a decrease in intermediate pore size (between a radius of 10 and $1 \mu \mathrm{m}$ ), with a $\mathrm{Hg}$ intrusion of $0.005 \mathrm{~mL} \cdot \mathrm{g}^{-1}$ for the control to 0.003 $\mathrm{mL} . \mathrm{g}^{-1}$ at month 10 and $0.001 \mathrm{~mL} \cdot \mathrm{g}^{-1}$ at month 16 and 26 . The microporosity, such as pores between 1 and $0.1 \mu \mathrm{m}$ radius, decreased from $0.046 \mathrm{~mL}^{-1} \mathrm{~g}^{-1}$ (control) to $0.023 \mathrm{~mL} \cdot \mathrm{g}^{-1}$ at month 26 . This could be explained by a shift of the month 26 curve; the main pore size was $0.09 \mu \mathrm{m}$ instead of $0.15 \mu \mathrm{m}$ for the control. In addition, the smallest pore size radius $(<0.1 \mu \mathrm{m})$ decreased clearly from month 10 with $0.054 \mathrm{~mL} . \mathrm{g}^{-1}$ instead of $0.072 \mathrm{~mL} . \mathrm{g}^{-1}$ for the control, but this trend was not confirmed for the remaining ageing period. Accordingly, the ageing of Courville stone with the settlement of 
microorganisms led to a decrease in the microporosity of pores with a radius of $1-0.1 \mu \mathrm{m}$. This filling of pores by the biofilm reduced their size and could partially explain the increase in smaller pores < $0.1 \mu \mathrm{m}$.

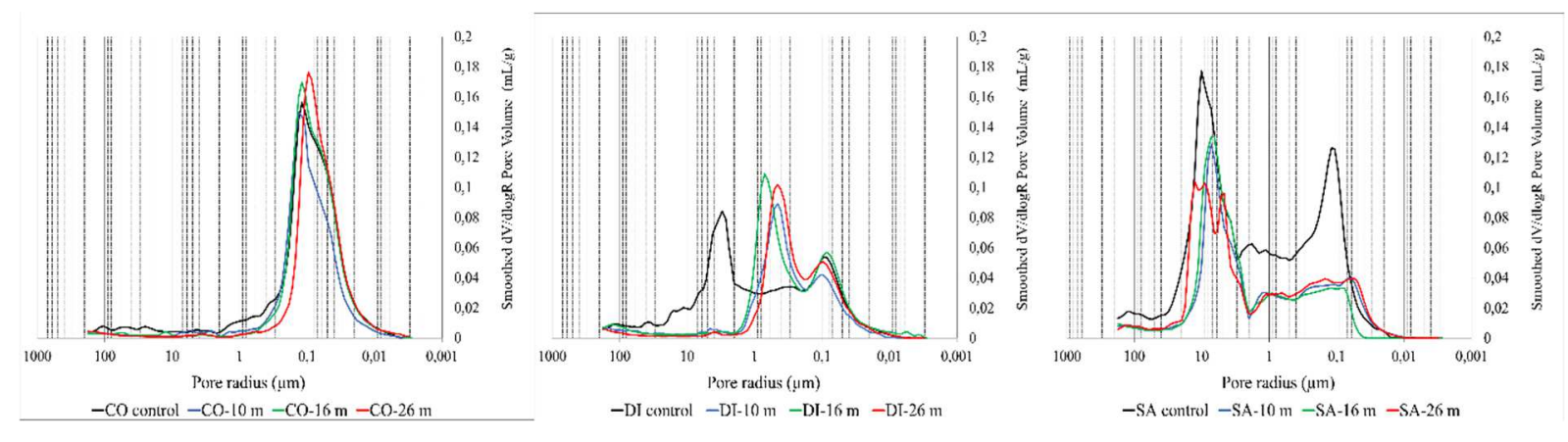

Fig. 8: Incremental mercury intrusion in relation to the pore size. Comparison of the pore access radii distribution at month 10, 16 and 26 for Courville (a), Ditrupa (b) and Savonnieres stones (c).

Ditrupa stone has a bimodal pore distribution, with two distinctive main pore radii at 3 and $0.08 \mu \mathrm{m}$ before the experiment. The porosity decreased slightly from $22.9 \%$ for the control to $17.9 \%$ at month 26. From month 10, $\mathrm{Hg}$ intrusion of pores higher than $10 \mu \mathrm{m}$ decreased from 0.014 to $0.006 \mathrm{~mL} . \mathrm{g}^{-1}$ and for pores between 10 and $1 \mu \mathrm{m}$ from 0.044 to $0.006 \mathrm{~mL} \cdot \mathrm{g}^{-1}$. Therefore, there was an obvious decrease in macroporosity. On the opposite, micropores comprising between 1 and $0.1 \mu \mathrm{m}$, with $0.033 \mathrm{~mL} . \mathrm{g}^{-1}$ for the control, increased to $0.050,0.059$ and $0.057 \mathrm{~mL} . \mathrm{g}^{-1}$, respectively, at months 10 , 16 and 26. These results were explained with the DI curves; the main pore radius decreased from $3 \mu \mathrm{m}$ for the control to $0.70-0.45 \mu \mathrm{m}$ between months 10,16 and 26 , whereas the main micropore size remained at $0.8-1.0 \mu \mathrm{m}$. Biocolonisation of the Ditrupa surface led to a filling of macropores and to a decrease in their size, followed by the emergence of a new, smaller pore class.

Originally, Savonnieres stone has a high porosity at $36.2 \%$ which is characterised by a bimodal pore distribution with main pore access radii at 10 and $0.1 \mu \mathrm{m}$. The porosity decreased to $24.1 \%$ for month 10 , at $23.5 \%$ for month 16 and at $25.8 \%$ for month 26 . Thus, porosity was decreased significantly at 10 months of ageing and remained stable thereafter. The main macropore radii at $10 \mu \mathrm{m}$ decreased strongly, and the peak of the curve shifted at a main pore radius of $7 \mu \mathrm{m}$ for months 10 and 16. It dropped continuously until month 26 , indicating significantly lower $\mathrm{Hg}$ intrusion, which suggests a blocking of some macropores. Moreover, the peak of the $0.1-\mu \mathrm{m}$ micropore radius was absent from months 10 to 26 . There was a clear obstruction of both micro- and macropores.

In conclusion, biological development affected the Courville stone surface less significantly than those of Ditrupa and Savonnieres. There was a slight decrease in Courville porosity, with a filling of micropores. Ditrupa showed a decrease in porosity, especially caused by the obstruction of the macropores $(>1 \mu \mathrm{m})$, which led to an increase in microporosity. Savonnieres porosity showed a stronger decrease, with a noticeable reduction of both micro- and macropores caused by microbial growth.

\subsection{SEM observations of biocolonisation}

SEM observations at the stone surfaces were carried out at month 10 in the aim to observe a preferential settlement of biofilm in function of the textural composition of stones and to specify the results of $\mathrm{Hg}$ porosimetry. A low microbial development was observed on Courville stones. It was located in the porosity of microfossils like miliolids (Fig. S2a) and mycelium of fungi developed around other micro-fossils as Dasycladaceae algae. Furthermore, clusters of micro-needles of calcite formed in the bigger pores (Fig. S2b). At the surface of Ditrupa stones, little patches of biofilm grew in the micropores and in the macropores formed by Ditrupa worm tubes (Fig. S2c). More microneedles of calcite were observed in the porosity of this stone than in Courville (Fig. S2d). For 
Savonnieres stones, biofilm patches grew primarily in the microporosity of oolit nuclei then in the macroporosity (Fig. S2e, f, g). Observations of stones at the end of the test showed more microneedles of calcite on Courville and the expansion of the biofilm in all stones. Lichen was clearly developed and mycelium filaments of fungi.

\section{Discussion}

The bacterial culture from biofilms enabled us to identify several species from isolates, of which all developed on the three types of limestone. Although cultivable bacteria represent only a small part of the bacterial diversity present on stones, this approach allowed us to determine species and their potential impact on the degradation of stones. Arthrobacter sp. showed strong growth, they belong to Actinobacteria and are often found on cultural heritage sites (Suihko et al., 2007; Mihajlovski et al., 2017). Those species are involved in carbonate biomineralisation similar to many soil bacteria ( $\mathrm{Li}$ et al., 2015), monument bacteria (Urzì et al., 2014; Jroundi et al., 2017); more specifically, theyplay a role in the precipitation of $\mathrm{Ca}-\mathrm{Mg}$ carbonate through the physicochemical change of the microenvironment around bacterial cells. Arthrobacter sp. could be associated to the formation of calcite in needle-like structures, as observed on both Courville and Ditrupa surfaces and already described as micrometric rod-like particles (Zhang et al., 2018, 2020). Moreover, pink Arthrobacter sp. and Arthrobacter agilis are associated to a rosy discoloration of stone cultural heritage (Tescari et al., 2018).

Bacillus species, widespread on the studied limestones are known for their ability to withstand extreme environments and to degrade stone buildings (Kiel and Gaylarde, 2006; Scheerer et al., 2009; Dyda et al., 2019). In our study, Bacillus subtilis, developed strongly from month 14, matching with the formation of calcite crystals in needle-like structures (Loisy et al., 1999; Nguyen et al., 2019). Moreover, they could reduce the water permeability of the stone and change the colour of the surface (Özdemir et al., 2020). Bacillus safensis, identified on all three stones, has a biodeterioration activity by the production of organic and inorganic acids (ElBaghdady et al., 2019). Stenotrophomonas sp., the only Proteobacteria phylum identified, can potentially produce of extracellular polymeric substances, promote the biofilm formation (Young et al., 2008) and plays a role in the stabilisation of biofilm structures on stone surfaces (Alakomi et al., 2006). Both actinomycetes, Microbacterium sp. and Rhodococcus sp. are commonly detected on building materials and can belong to pioneer biofilms (Abdulla et al., 2008; Urzì et al., 2014; Zanardini et al., 2016; Romani et al., 2019).

Bacterial growth was considerably higher on Courville and Ditrupa than on Savonnieres, where bacteria developed weakly during the whole experiment. The porosity of Courville, made of micropores but well connected, promoted bacterial growth whereas large pores in most Savonnieres stones facilitated the development of fungi and phototrophic microorganisms. Indeed, the biocolonisation monitored on Savonnieres by colour variations was detected earlier and the two peaks of $\Delta \mathrm{E}_{\mathrm{ab}}^{*}$ (in Nov. 2017 and Mar. 2018) were significantly higher for this stone than for the others. Moreover, the first peak in Nov. 2017 appeared also in the chlorophyll $a$ content and in fluorescence data, which revealed that the sharp colour change was associated to a rapid growth of photosynthetic microorganisms on the three stones but more specifically on Savonnieres. During the 2 whole years of the test period, phototrophic development was noticed during each winter. In temperate climates, winter is the wettest and coldest season. Thus, water seemed to be a key factor, for the growth of photosynthetic microorganisms on the stones.

The data of mercury injection porosimetry showed that the porous network of Courville was less impacted by biofilm colonisation; however, it was the less colonised stone. Ditrupa, which had a micro- and a macroporosity, showed a net decrease specially of the macropores by the filling of the biofilm. On Savonnieres, the porous network considerably changed, which was noticed by the decrease in microporosity. The SEM observations at month 10 showed that biofilm growth preferably started in the micropores located in the microcrystals of calcite, composing the oolite nuclei. Furthermore, the macropores were also impacted by the biofilm, which grew in pores located in the partial calcite cement between oolites. On the one hand, the macroporosity provided the 
microorganisms with water over a long period and delayed the desiccation during the dry periods; on the other hand, the biofilm strongly decreased the porosity and changed the natural properties of the stone. Savonnieres was more bioreceptive than both Lutetian stones.

\section{Conclusions}

The microporosity of Courville stones promoted the progressive growth of bacteria, especially Arthrobacter sp., Arthrobacter agilis, which could form needle-like calcite structures, but it limited the colonisation by other microorganisms such as phototrophs. In contrast, Savonnieres, which has a high macroporosity and less micropores, did not facilitate bacterial growth but promoted a more rapid development of phototrophs and other microorganisms such as fungi. Ditrupa showed an intermediate biocolonisation despite the lowest porosity; it was characterised by the highest bacterial growth, most likely because of its well-developed microporosity. Moreover, it displayed a high biocolonisation by phototrophs, which developed in the macropores. Savonnieres has been used for many centuries as a replacement stone for Courville and Ditrupa because of its similar natural colour; also, it can easily be cut and has been used for the creation of numerous sculptures on Gothic monuments. Nevertheless, it has a higher bioreceptivity to photosynthetic microorganisms, which led to a higher discolouration of the stone and promoted the development of other plants and an earlier biodegradation of this stone.

\section{Acknowledgements:}

The authors wish to thank M. Marlat, Director of the residential school Sacré Coeur in Rheims city for the authorization to set up the outdoor station in the grounds of the secondary school.

\section{Disclosure statement:}

No potential conflict of interest was reported by the author(s).

\section{References:}

Abdulla, H., May, E., Bahgat, M., Dewedar, A., 2008. Characterisation of actinomycetes isolated from ancient stone and their potential for deterioration. Pol J Microbiol 57, 213-220.

Alakomi, H.-L., Paananen, A., Suihko, M.-L., Helander, I.M., Saarela, M., 2006. Weakening Effect of Cell Permeabilizers on Gram-Negative Bacteria Causing Biodeterioration. Appl. Environ. Microbiol. 72, 4695-4703. https://doi.org/10.1128/AEM.00142-06

Bellopede, R., Castelletto, E., Marini, P., 2016. Ten years of natural ageing of calcareous stones. Engineering Geology 211, 19-26.

Bruno, L., Rugnini, L., Spizzichino, V., Caneve, L., Canini, A., Ellwood, N.T.W., 2019. Biodeterioration of Roman hypogea: the case study of the Catacombs of SS. Marcellino and Pietro (Rome, Italy). Annals of Microbiology 69, 1023-1032.

Cutler, N.A., Viles, H.A., Ahmad, S., McCabe, S., Smith, B.J., 2013. Algal "greening" and the conservation of stone heritage structures. Science of the Total Environment 442, 152-164. https://doi.org/10.1016/j.scitotenv.2012.10.050

Durnan, N., 2015. Limestone, in: Stone Conservation: Principles and Practice. Donhead, pp. 161-189.

Dyda, M., Pyzik, A., Wilkojc, E., Kwiatkowska-Kopka, B., Sklodowska, A., 2019. Bacterial and Fungal Diversity Inside the Medieval Building Constructed with Sandstone Plates and Lime Mortar as an Example of the Microbial Colonization of a Nutrient-Limited Extreme Environment (Wawel Royal Castle, Krakow, Poland). Microorganisms 7, 416.

ElBaghdady, K.Z., Tolba, S.T., Houssien, S.S., 2019. Biogenic deterioration of Egyptian limestone monuments: treatment and conservation. Journal of Cultural Heritage 38, 118-125. https://doi.org/10.1016/j.culher.2019.02.005

European Committee for Standardization, 2010. NF EN 15801 - Conservation of cultural property test methods - determination of water absorption by capillarity. La Plaine Saint-Denis.

European committee for Standardization, 2007. NF EN 1936 - Natural stone test method Determination of real density and apparent density, and of total and open porosity, in: AFNOR Edition. La Plaine Saint-Denis. 
Fronteau, G., 2000. L'Oolithe vacuolaire: caractéristiques, mise en oeuvre et altération. Bulletin d'information des géologues du Bassin de Paris 37, 34-38.

Fronteau, G., Barbin, V., Pascal, A., 1999. Impact of sedimentary-diagenetic facies on weathering of carbonate building stone - Impact du faciès sédimento-diagénétique sur l'altération en œuvre d'un géomatériau calcaire. Comptes Rendus de l'Académie des Sciences - Series IIA - Earth and Planetary Science 328, 671-677. https://doi.org/10.1016/S1251-8050(99)80176-1

Fronteau, G., Moreau, C., Thomachot-Schneider, C., Barbin, V., 2010. Variability of some Lutetian building stones from the Paris Basin, from characterisation to conservation. Engineering Geology, Natural stones for historical monuments, testing, durability and provenance 115, 158-166. https://doi.org/10.1016/j.enggeo.2009.08.001

Gibeaux, S., Martínez-Garrido, M.I., Vázquez, P., Thomachot-Schneider, C., Fort, R., 2018. Wireless environmental monitoring coupled to NDT for decay risk analysis (at St. Joseph Chapel in Reims, France). Sensors and Actuators A: Physical 272, 102-113.

Grossi, C.M., Brimblecombe, P., Esbert, R.M., Alonso, F.J., 2007. Color changes in architectural limestones from pollution and cleaning. Color Res. Appl. 32, 320-331. https://doi.org/10.1002/col.20322

Gulotta, D., Toniolo, L., 2019. Conservation of the Built Heritage: Pilot Site Approach to Design a Sustainable Process. Heritage 2, 797-812. https://doi.org/10.3390/heritage2010052

Huby, E., Thomachot-Schneider, C., Vázquez, P., Fronteau, G., 2020. Use of micro-climatic monitoring to assess potential stone weathering on a monument: example of the Saint-Remi Basilica (Reims, France). Environmental Monitoring and Assessment 192, 1-25.

Hueck, H.J., 2001. The biodeterioration of materials - an appraisal. International Biodeterioration \& Biodegradation, Special Millennium Issue: The First Quarter Century 48, 5-11. https://doi.org/10.1016/S0964-8305(01)00061-0

Jroundi, F., Schiro, M., Ruiz-Agudo, E., Elert, K., Martín-Sánchez, I., González-Muñoz, M.T., Rodriguez-Navarro, C., 2017. Protection and consolidation of stone heritage by selfinoculation with indigenous carbonatogenic bacterial communities. Nature Communications 8 , 279. https://doi.org/10.1038/s41467-017-00372-3

Kiel, G., Gaylarde, C.C., 2006. Bacterial diversity in biofilms on external surfaces of historic buildings in Porto Alegre. World journal of microbiology and biotechnology 22, 293-297.

Li, X., Chopp, D.L., Russin, W.A., Brannon, P.T., Parsek, M.R., Packman, A.I., 2015. Spatial patterns of carbonate biomineralization in biofilms. Applied and environmental microbiology 81, 7403-7410.

Loisy, C., Verrecchia, E.P., Dufour, P., 1999. Microbial origin for pedogenic micrite associated with a carbonate paleosol (Champagne, France). Sedimentary Geology 126, 193-204. https://doi.org/10.1016/S0037-0738(99)00040-8

Malam Issa, O., 1999. Etude du rôle des croûtes microbiotiques dans les sols de deux écosystèmes sahéliens (jachères et brousse tigrée) au Niger: micromorphologie, propriétés physiques et biogéochimiques (These de doctorat). Orléans.

Mihajlovski, A., Gabarre, A., Seyer, D., Bousta, F., Di Martino, P., 2017. Bacterial diversity on rock surface of the ruined part of a French historic monument: The Chaalis abbey. International Biodeterioration \& Biodegradation 120, 161-169.

Nguyen, T.H., Ghorbel, E., Fares, H., Cousture, A., 2019. Bacterial self-healing of concrete and durability assessment. Cement and Concrete Composites 104, 103340. https://doi.org/10.1016/j.cemconcomp.2019.103340

Özdemir, A., Erguven, G.O., Adar, E., Nuhoglu, Y., 2020. Investigation on Microbial Biodeterioration of the Stone Monuments in Yildiz Technical University-Yildiz Campus-Istanbul-Turkey. Curr Microbiol 77, 3288-3299. https://doi.org/10.1007/s00284-020-02171-4

Pfendler, S., Borderie, F., Bousta, F., Alaoui-Sossé, L., Alaoui-Sossé, B., Aleya, L., 2018. Comparison of biocides, allelopathic substances and UV-C as treatments for biofilm proliferation on heritage monuments. Journal of Cultural Heritage 33, 117-124.

Pozo-Antonio, J.S., Montojo, C., López de Silanes, M.E., de Rosario, I., Rivas, T., 2017. In situ evaluation by colour spectrophotometry of cleaning and protective treatments in granitic Cultural Heritage. International Biodeterioration \& Biodegradation 123, 251-261. https://doi.org/10.1016/j.ibiod.2017.07.004 
Přikryl, R., Török, Á., 2010. Natural stones for monuments: their availability for restoration and evaluation. Geological Society, London, Special Publications 333, 1-9. https://doi.org/10.1144/SP333.1

Reffuveille, F., Josse, J., Velard, F., Lamret, F., Varin-Simon, J., Dubus, M., Haney, E.F., Hancock, R.E.W., Mongaret, C., Gangloff, S.C., 2018. Bone Environment Influences Irreversible Adhesion of a Methicillin-Susceptible Staphylococcus aureus Strain. Front Microbiol 9, 2865. https://doi.org/10.3389/fmicb.2018.02865

Roels, S., Carmeliet, J., Hens, H., Elsen, J., 2000. Microscopic analysis of imbibition processes in oolitic limestone. Geophysical Research Letters 27, 3533-3536. https://doi.org/10.1029/1999GL008471

Romani, M., Carrion, C., Fernandez, F., Intertaglia, L., Pecqueur, D., Lebaron, P., Lami, R., 2019. High bacterial diversity in pioneer biofilms colonizing ceramic roof tiles. International Biodeterioration \& Biodegradation 144, 104745. https://doi.org/10.1016/j.ibiod.2019.104745

Rousset-Tournier, B., Mazerolle, F., Géraud, Y., Jeannette, D., 2003. Rock drying tests monitored by $\mathrm{X}$-ray computed tomography - the effect of saturation methods on drying behaviour. Geological Society, London, Special Publications 215, 117-125.

Scheerer, S., Ortega-Morales, O., Gaylarde, C., 2009. Microbial deterioration of stone monumentsan updated overview. Advances in applied microbiology 66, 97-139.

Siegesmund, S., Török, Á., 2014. Building Stones, in: Siegesmund, S., Snethlage, R. (Eds.), Stone in Architecture: Properties, Durability. Springer, Berlin, Heidelberg, pp. 11-95. https://doi.org/10.1007/978-3-642-45155-3_2

Suihko, M.-L., Alakomi, H.-L., Gorbushina, A., Fortune, I., Marquardt, J., Saarela, M., 2007. Characterization of aerobic bacterial and fungal microbiota on surfaces of historic Scottish monuments. Systematic and Applied Microbiology 30, 494-508. https://doi.org/10.1016/j.syapm.2007.05.001

Tescari, M., Frangipani, E., Caneva, G., Casanova Municchia, A., Sodo, A., Visca, P., 2018. Arthrobacter agilis and rosy discoloration in "Terme del Foro" (Pompeii, Italy). International Biodeterioration \& Biodegradation 130, 48-54. https://doi.org/10.1016/j.ibiod.2018.03.015

Thompson, J.D., Gibson, T.J., Higgins, D.G., 2002. Multiple sequence alignment using ClustalW and ClustalX. Current protocols in bioinformatics / editoral board, Andreas D. Baxevanis ... [et al.] Chapter 2.

Turmel, A., 2014. Répartition et utilisation des pierres et géomatériaux de construction dans le bâti du Pays rémois - analyse spatiale et propriétés pétrophysiques - (thesis). http://www.theses.fr. Reims.

Turmel, A., Fronteau, G., Thomachot-Schneider, C., Moreau, C., Chalumeau, L., Barbin, V., 2014. Stone uses in Reims Cathedral: provenance, physical properties and restoration phases. Geological Society, London, Special Publications 391, 17-30. https://doi.org/10.1144/SP391.7

Urzì, C., De Leo, F., Bruno, L., Pangallo, D., Krakova, L., 2014. New species description, biomineralization processes and biocleaning applications of Roman Catacombs-living bacteria. The Conservation of Subterranean Cultural Heritage 65-72.

Vázquez, P., Menéndez, B., Denecker, M.F., Thomachot-Schneider, C., 2016. Comparison between petrophysical properties, durability and use of two limestones of the Paris region. Geological Society, London, Special Publications 416, 203-216.

Vázquez-Nion, D., Sanmartín, P., Silva, B., Prieto, B., 2013. Reliability of color measurements for monitoring pigment content in a biofilm-forming cyanobacterium. International Biodeterioration \& Biodegradation 84, 220-226. https://doi.org/10.1016/j.ibiod.2012.05.037

Young, M.E., Alakomi, H.-L., Fortune, I., Gorbushina, A.A., Krumbein, W.E., Maxwell, I., McCullagh, C., Robertson, P., Saarela, M., Valero, J., 2008. Development of a biocidal treatment regime to inhibit biological growths on cultural heritage: BIODAM. Environmental Geology 56, 631-641.

Zanardini, E., May, E., Inkpen, R., Cappitelli, F., Murrell, J.C., Purdy, K.J., 2016. Diversity of archaeal and bacterial communities on exfoliated sandstone from Portchester Castle (UK). $\begin{array}{lllll}\text { International Biodeterioration } \quad \& \quad \text { Biodegradation } & 109, \quad 87 .\end{array}$ https://doi.org/10.1016/j.ibiod.2015.12.021 
Zhang, C., Li, F., Li, X., Li, L., Liu, L., 2018. The roles of Mg over the precipitation of carbonate and morphological formation in the presence of Arthrobacter sp. strain MF-2. Geomicrobiology Journal 35, 545-554.

Zhang, C., Li, X., Lyu, J., Li, F., 2020. Comparison of carbonate precipitation induced by Curvibacter sp. HJ-1 and Arthrobacter sp. MF-2: Further insight into the biomineralization process. Journal of Structural Biology 212, 107609. https://doi.org/10.1016/j.jsb.2020.107609

\section{Supplementary data}

\begin{tabular}{|l|l|l|l|l|l|}
\hline Month & $\begin{array}{l}\text { Rainfall } \\
(\mathrm{mm})\end{array}$ & $\begin{array}{l}\text { Average } \\
\text { temperature }\left({ }^{\circ} \mathrm{C}\right)\end{array}$ & $\begin{array}{l}\text { Average minimum } \\
\text { temperature }\left({ }^{\circ} \mathrm{C}\right)\end{array}$ & $\begin{array}{l}\text { Average maximum } \\
\text { temperature }\left({ }^{\circ} \mathrm{C}\right)\end{array}$ & $\begin{array}{l}\text { Solar insolation } \\
(\text { W.m }\end{array}$
\end{tabular}

Table S1: Climatic data from January 2017 to April 2019. comprising the cumulative rainfall (mm). the average temperature $\left({ }^{\circ} \mathrm{C}\right)$. the average minimum temperature $\left({ }^{\circ} \mathrm{C}\right)$. the maximum temperature $\left({ }^{\circ} \mathrm{C}\right)$ (METEOFRANCE) and the solar radiation $\left(\mathrm{W} . \mathrm{m}^{-2}\right.$ ) at the time of the fluorescence measurements (https://www.data.gouv.fr). 


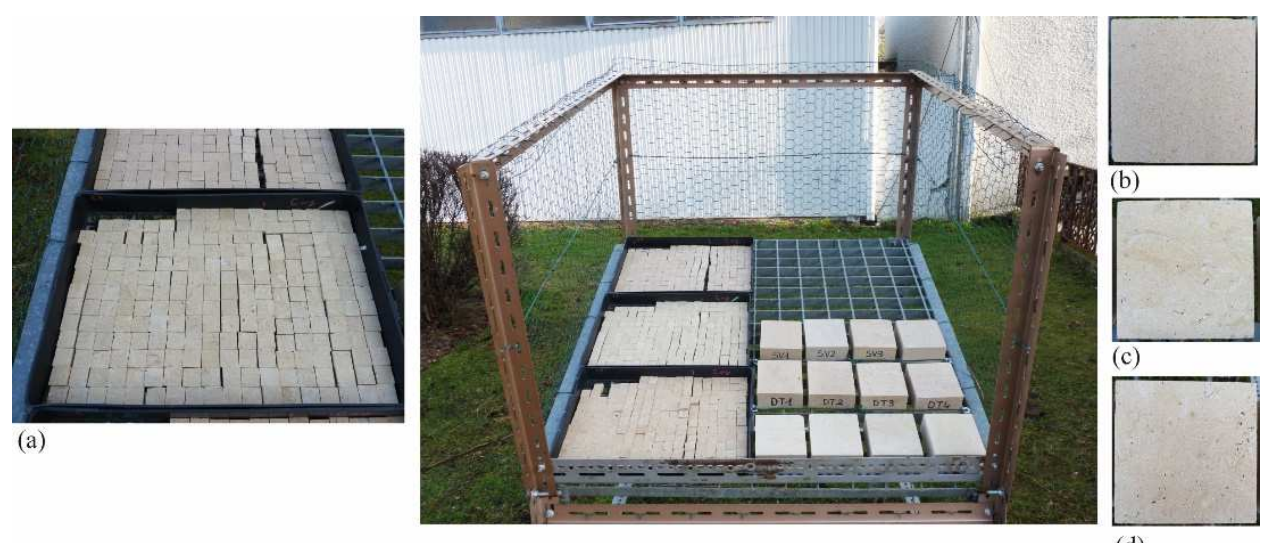

(d)

Fig.S1: Platform of stone samples exposure in outdoor. Smaller samples have been collected for the laboratory analyses (zoom of the Courville sample tray (a)) and bigger samples (four for each type of stone) stayed in-situ for the duration of the test for colorimetry and Chl.a fluorescence measurements (zoom of Savonnieres sample (b), Ditrupa sample (c), Courville sample (d)).

\begin{tabular}{|c|c|c|c|c|c|c|c|c|}
\hline \multicolumn{9}{|c|}{ COURVILLE } \\
\hline \multirow{2}{*}{\multicolumn{2}{|c|}{$\begin{array}{l}\text { Test time (month) } \\
\text { Collecting month }\end{array}$}} & 6 & 9 & 14 & 18 & 21 & 23 & 26 \\
\hline & & Apr-17 & Jul-17 & Dec-17 & Apr-18 & Jul-18 & Sept-18 & Dec-18 \\
\hline \multirow{7}{*}{ 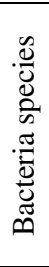 } & Red Arthrobacter sp. & 13.5 & 170.8 & 87.5 & 72.5 & 136.8 & 144.0 & 49.8 \\
\hline & Rhodococcus sp. & 4.3 & 8.5 & 0.0 & 0.0 & 0.5 & 1.3 & 1.3 \\
\hline & Microbacterium ph. & 3.3 & 5.0 & 56.3 & 89.5 & 30.5 & 38.3 & 81.5 \\
\hline & Bacillus subtilis & 0.0 & 1.8 & 112.5 & 7.5 & 146.8 & 15.0 & 70.0 \\
\hline & Bacillus safensis & 1.5 & 13.5 & 3.8 & 22.5 & 24.5 & 21.0 & 43.3 \\
\hline & Pink Arthrobacter sp. & 2.5 & 20.3 & 0.0 & 160.0 & 123.5 & 440.0 & 315.3 \\
\hline & Stenophomonas sp. & 0.5 & 6.5 & 125.0 & 57.0 & 89.5 & 38.0 & 142.5 \\
\hline & Total & 25.5 & 226.3 & 385.0 & 409.0 & 552.0 & 697.5 & 703.5 \\
\hline
\end{tabular}

(a)

\begin{tabular}{|c|c|c|c|c|c|c|c|c|}
\hline \multicolumn{9}{|c|}{ DITRUPA } \\
\hline \multirow{2}{*}{\multicolumn{2}{|c|}{$\begin{array}{l}\text { Test time (month) } \\
\text { Collecting month }\end{array}$}} & 6 & 9 & 14 & 18 & 21 & 23 & 26 \\
\hline & & Apr-17 & Jul-17 & Dec-17 & Apr-18 & Jul-18 & Sept-18 & Dec-18 \\
\hline \multirow{7}{*}{ 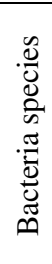 } & Arthrobacter sp. & 45.3 & 65.5 & 167.5 & 54.3 & 90.0 & 167.8 & 85.8 \\
\hline & Rhodococcus sp. & 3.3 & 2.8 & 27.0 & 3.0 & 0.3 & 1.5 & 0.8 \\
\hline & Microbacterium ph. & 2.5 & 7.8 & 40.0 & 71.0 & 57.0 & 117.8 & 97.5 \\
\hline & Bacillus subtilis & 2.5 & 0.0 & 37.5 & 10.8 & 89.0 & 0.3 & 75.0 \\
\hline & Bacillus safensis & 3.8 & 1.5 & 33.3 & 11.0 & 20.8 & 7.5 & 117.5 \\
\hline & Pink Arthrobacter sp. & 6.3 & 24.8 & 3.8 & 43.8 & 82.8 & 68.0 & 262.0 \\
\hline & Stenophomonas sp. & 6.5 & 30.3 & 39.8 & 13.3 & 115.0 & 2.5 & 326.0 \\
\hline & Total & 70.0 & 132.5 & 348.8 & 207.0 & 454.8 & 365.3 & 964.5 \\
\hline
\end{tabular}

(b)

\begin{tabular}{|c|c|c|c|c|c|c|c|c|}
\hline \multicolumn{9}{|c|}{ SAVONNIERES } \\
\hline \multirow{2}{*}{\multicolumn{2}{|c|}{$\frac{\text { Test time (month) }}{\text { Month of collecting }}$}} & 6 & 9 & 14 & 18 & 21 & 23 & 26 \\
\hline & & Apr-17 & Jul-17 & Dec-17 & Apr-18 & Jul-18 & Sept-18 & Dec-18 \\
\hline \multirow{7}{*}{ 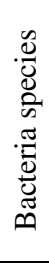 } & Arthrobacter sp. & 0.5 & 22.8 & 17.5 & 19.5 & 16.8 & 86.5 & 63.3 \\
\hline & Rhodococcus sp. & 1.8 & 0.3 & 12.5 & 1.5 & 2.3 & 0.8 & 9.8 \\
\hline & Microbacterium ph. & 1.5 & 1.5 & 14.8 & 8.8 & 5.0 & 5.3 & 69.5 \\
\hline & Bacillus subtilis & 0.0 & 0.3 & 8.8 & 5.8 & 42.3 & 25.0 & 49.0 \\
\hline & Bacillus safensis & 0.3 & 1.3 & 5.0 & 7.8 & 26.5 & 20.3 & 36.8 \\
\hline & Pink Arthrobacter sp. & 0.3 & 0.0 & 9.8 & 27.3 & 11.5 & 264.0 & 16.8 \\
\hline & Stenophomonas sp. & 3.0 & 0.8 & 12.5 & 0.0 & 100.0 & 28.5 & 9.8 \\
\hline & Total & 7.3 & 26.8 & 80.8 & 70.5 & 204.3 & 430.3 & 254.8 \\
\hline
\end{tabular}

(c)

Table S2: Number of colonies formed on the stone surface $\left(\mathrm{CFU} / \mathrm{cm}^{2}\right)$ on agar plates from triplicates of Courville (a). Ditrupa (b) and Savonnieres stones (c) at 6. 9. 14. 1821.23 and 26 months for the outdoor ageing test. 


\begin{tabular}{|l|l|l|l|}
\hline Stones & $\mathrm{L}^{*}$ & $\mathrm{a}^{*}$ & $\mathrm{~b}^{*}$ \\
\hline Courville (CV) & $79.8 \pm 1.1$ & $1.7 \pm 0.2$ & $12.7 \pm 1.7$ \\
\hline Ditrupa (DI) & $76.0 \pm 1.4$ & $2.9 \pm 0.2$ & $11.8 \pm 0.9$ \\
\hline Savonnieres (SV) & $76.6 \pm 1.2$ & $2.9 \pm 0.6$ & $13.0 \pm 2.3$ \\
\hline
\end{tabular}

Table S3: Colour data of the three natural limestones (Courville, Ditrupa and Savonnieres) before the outdoor ageing experiment. $L^{*}, a^{*}, b^{*}$ have been calculated by the average of 25 measurements carried out on 4 samples $(10 \times 10 \times 5 \mathrm{~cm}$ dimension).

\begin{tabular}{|l|l|l|l|l|l|l|l|l|}
\hline month & $\Delta \mathrm{E}^{*} . \mathrm{CO}$ & $\Delta \mathrm{E}^{*} . \mathrm{CO} . \mathrm{SD}$ & $\Delta \mathrm{L}^{*} . \mathrm{CO}$ & $\Delta \mathrm{L}^{*} . \mathrm{CO} . \mathrm{SD}$ & $\Delta \mathrm{a}^{*} \cdot \mathrm{CO}$ & $\Delta \mathrm{a}^{*} . \mathrm{CO} . \mathrm{SD}$ & $\Delta \mathrm{b}^{*} \cdot \mathrm{CO}$ & $\Delta \mathrm{b}^{*}$.CO.SD \\
\hline Jan-17 & 12.6 & 0.9 & -10.6 & 0.7 & 0.4 & 0.2 & 6.9 & 0.8 \\
\hline Feb-17 & 11.2 & 1.0 & -9.6 & 0.8 & 0.2 & 0.2 & 5.6 & 0.9 \\
\hline Mar-17 & 2.9 & 0.8 & -1.3 & 0.9 & -0.7 & 0.2 & 2.3 & 0.9 \\
\hline Apr-17 & 3.1 & 0.8 & -0.6 & 0.8 & -0.7 & 0.2 & 2.8 & 0.9 \\
\hline May-17 & 2.9 & 0.9 & -0.1 & 1.0 & -0.5 & 0.3 & 2.6 & 1.1 \\
\hline Jun-17 & 3.0 & 0.8 & -0.5 & 0.8 & -0.6 & 0.2 & 2.7 & 0.9 \\
\hline Jul-17 & 3.4 & 0.5 & -0.6 & 1.0 & -0.4 & 0.6 & 2.8 & 1.1 \\
\hline Aug-17 & 3.8 & 1.0 & -1.0 & 0.9 & -0.5 & 0.2 & 3.5 & 1.0 \\
\hline Sep-17 & 4.6 & 1.1 & -1.8 & 0.9 & -0.6 & 0.3 & 4.1 & 1.0 \\
\hline Oct-17 & 7.8 & 1.2 & -4.6 & 1.0 & -0.6 & 0.4 & 6.2 & 1.0 \\
\hline Nov-17 & 11.5 & 1.6 & -9.0 & 1.2 & -0.5 & 0.5 & 7.1 & 1.5 \\
\hline Dec-17 & 8.8 & 1.7 & -5.8 & 1.4 & -1.7 & 0.6 & 6.3 & 1.3 \\
\hline Jan-18 & 10.8 & 2.5 & -7.8 & 2.4 & -1.4 & 0.3 & 7.2 & 1.5 \\
\hline Feb-18 & 12.7 & 3.0 & -10.9 & 2.8 & -0.4 & 0.4 & 6.4 & 1.4 \\
\hline Mar-18 & 7.6 & 1.5 & -6.1 & 1.4 & -0.6 & 0.4 & 4.3 & 1.0 \\
\hline Apr-18 & 6.8 & 1.6 & -5.6 & 1.6 & -0.8 & 0.4 & 3.7 & 1.1 \\
\hline May-18 & 8.0 & 1.6 & -6.8 & 1.6 & -0.9 & 0.3 & 4.1 & 1.1 \\
\hline Jun-18 & 7.5 & 1.5 & -6.1 & 1.5 & -0.6 & 0.3 & 4.1 & 1.0 \\
\hline Jul-18 & 7.0 & 1.6 & -6.0 & 1.5 & -0.6 & 0.3 & 4.2 & 1.1 \\
\hline Aug-18 & 7.1 & 1.5 & -5.6 & 1.5 & -0.5 & 0.3 & 4.2 & 1.1 \\
\hline Sep-18 & 7.6 & 1.6 & -6.0 & 1.5 & -0.5 & 0.3 & 4.5 & 1.1 \\
\hline Oct-18 & 8.3 & 1.6 & -6.8 & 1.5 & -0.8 & 0.3 & 4.7 & 1.1 \\
\hline Nov-18 & 10.7 & 2.4 & -9.0 & 2.1 & -1.1 & 0.3 & 5.7 & 1.6 \\
\hline Dec-18 & 11.2 & 1.9 & -9.7 & 1.8 & -1.4 & 0.3 & 5.4 & 1.5 \\
\hline Jan-19 & 12.0 & 2.6 & -10.6 & 2.4 & -0.9 & 0.3 & 5.4 & 1.6 \\
\hline Feb-19 & 6.6 & 1.7 & -5.8 & 1.8 & -0.7 & 0.3 & 2.8 & 1.1 \\
\hline Mar-19 & 10.5 & 1.8 & -10.1 & 1.8 & -0.4 & 0.2 & 2.6 & 1.1 \\
\hline Apr-19 & 9.6 & 1.7 & -9.2 & 1.8 & -0.1 & 0.2 & 2.5 & 1.1 \\
\hline
\end{tabular}

Table S4: Courville colour variations through the experiment time. The variation of colour parameters $\Delta \mathrm{E}_{\mathrm{ab}}, \Delta \mathrm{L}, \Delta \mathrm{a}, \Delta \mathrm{b}$ has been calculated from the starting of the ageing test in October 2016 (T0) for January 2017 to April 2020. 


\begin{tabular}{|l|l|l|l|l|l|l|l|l|}
\hline month & $\Delta \mathrm{E}^{*} . \mathrm{DI}$ & $\Delta \mathrm{E}^{*} . \mathrm{DI} . \mathrm{SD}$ & $\Delta \mathrm{L}^{*} . \mathrm{DI}$ & $\Delta \mathrm{L}^{*} . \mathrm{DI} . \mathrm{SD}$ & $\Delta \mathrm{a}^{*} . \mathrm{DI}$ & $\Delta \mathrm{a}^{*} . \mathrm{DI} . \mathrm{SD}$ & $\Delta \mathrm{b}^{*} . \mathrm{DI}$ & $\Delta \mathrm{b}^{*} . \mathrm{DI} . \mathrm{SD}$ \\
\hline Jan-17 & 13.9 & 1.8 & -11.1 & 1.2 & 1.7 & 0.4 & 8.2 & 1.5 \\
\hline Feb-17 & 5.1 & 1.7 & -4.1 & 1.1 & 0.2 & 0.3 & 2.8 & 1.4 \\
\hline Mar-17 & 2.4 & 0.9 & -1.3 & 0.7 & -0.2 & 0.2 & 1.9 & 0.8 \\
\hline Apr-17 & 2.5 & 0.9 & -1.2 & 0.7 & -0.2 & 0.2 & 2.2 & 0.9 \\
\hline May-17 & 2.4 & 1.0 & -0.7 & 1.2 & 0.0 & 0.3 & 1.9 & 1.0 \\
\hline Jun-17 & 2.2 & 0.9 & -0.6 & 0.7 & -0.1 & 0.2 & 2.0 & 0.8 \\
\hline Jul-17 & 3.1 & 0.8 & -0.1 & 1.0 & -0.4 & 0.5 & 2.0 & 1.3 \\
\hline Aug-17 & 2.8 & 1.0 & -1.0 & 0.8 & -0.1 & 0.3 & 2.6 & 1.0 \\
\hline Sep-17 & 3.5 & 1.0 & -1.4 & 0.8 & -0.2 & 0.4 & 3.1 & 0.9 \\
\hline Oct-17 & 8.7 & 1.2 & -5.7 & 1.0 & 0.3 & 0.6 & 6.5 & 1.0 \\
\hline Nov-17 & 9.8 & 1.4 & -7.3 & 1.2 & 0.1 & 0.7 & 6.5 & 1.0 \\
\hline Dec-17 & 6.7 & 1.3 & -4.3 & 1.1 & -1.0 & 0.5 & 4.9 & 1.0 \\
\hline Jan-18 & 7.3 & 1.4 & -5.2 & 1.2 & -0.9 & 0.4 & 5.0 & 1.1 \\
\hline Feb-18 & 7.1 & 1.8 & -5.6 & 1.6 & -0.4 & 0.3 & 4.2 & 1.2 \\
\hline Mar-18 & 6.8 & 1.4 & -5.2 & 1.2 & -0.4 & 0.4 & 4.2 & 1.1 \\
\hline Apr-18 & 6.2 & 1.3 & -5.0 & 1.2 & -0.4 & 0.3 & 3.5 & 1.1 \\
\hline May-18 & 7.2 & 1.4 & -5.9 & 1.3 & -0.6 & 0.4 & 4.0 & 1.0 \\
\hline Jun-18 & 6.8 & 1.4 & -5.5 & 1.4 & -0.3 & 0.4 & 3.8 & 1.1 \\
\hline Jul-18 & 6.4 & 1.4 & -5.4 & 1.2 & -0.3 & 0.4 & 3.9 & 1.1 \\
\hline Aug-18 & 6.4 & 1.4 & -5.2 & 1.3 & -0.3 & 0.4 & 3.7 & 1.1 \\
\hline Sep-18 & 6.8 & 1.4 & -5.5 & 1.3 & -0.4 & 0.4 & 3.8 & 1.0 \\
\hline Oct-18 & 7.6 & 1.3 & -6.4 & 1.2 & -0.6 & 0.4 & 3.9 & 1.0 \\
\hline Nov-18 & 8.8 & 1.4 & -7.4 & 1.3 & -1.2 & 0.4 & 4.6 & 1.1 \\
\hline Dec-18 & 10.1 & 1.5 & -8.7 & 1.4 & -1.3 & 0.3 & 4.8 & 1.2 \\
\hline Jan-19 & 8.3 & 1.6 & -7.2 & 1.6 & -1.2 & 0.4 & 3.8 & 1.3 \\
\hline Feb-19 & 9.8 & 1.6 & -9.1 & 1.5 & -0.6 & 0.3 & 3.3 & 1.0 \\
\hline Mar-19 & 9.7 & 1.6 & -9.2 & 1.5 & -0.4 & 0.2 & 3.0 & 1.0 \\
\hline Apr-19 & 9.5 & 1.6 & -9.0 & 1.6 & -0.2 & 0.3 & 2.9 & 1.0 \\
\hline & & & & & & & & \\
\hline
\end{tabular}

Table S5: Ditrupa colour variations through the experiment time. The variation of colour parameters $\Delta \mathrm{E}_{\mathrm{ab}}, \Delta \mathrm{L}, \Delta \mathrm{a}, \Delta \mathrm{b}$ is calculated from the starting of the ageing test in October 2016 (T0) for January 2017 to April 2020. 


\begin{tabular}{|l|l|l|l|l|l|l|l|l|}
\hline month & $\Delta \mathrm{E}^{*} . \mathrm{SA}$ & $\Delta \mathrm{E}^{*} . \mathrm{SA} . \mathrm{SD}$ & $\Delta \mathrm{L}^{*} . \mathrm{SA}$ & $\Delta \mathrm{L}^{*}$.SA.SD & $\Delta \mathrm{a}^{*} . \mathrm{SA}$ & $\Delta \mathrm{a}^{*}$.SA.SD & $\Delta \mathrm{b}^{*} . \mathrm{SA}$ & $\Delta \mathrm{b}^{*}$.SA.SD \\
\hline Jan-17 & 8.4 & 1.2 & -7.0 & 1.1 & 0.6 & 0.3 & 4.5 & 0.9 \\
\hline Feb-17 & 12.8 & 1.0 & -11.9 & 0.8 & 0.9 & 0.3 & 4.5 & 0.8 \\
\hline Mar-17 & 1.5 & 0.3 & -1.2 & 0.5 & -0.6 & 0.2 & -0.2 & 0.5 \\
\hline Apr-17 & 0.9 & 0.3 & -0.4 & 0.6 & -0.5 & 0.2 & -0.2 & 0.5 \\
\hline May-17 & 1.2 & 0.4 & -0.1 & 0.8 & -0.7 & 0.2 & -0.1 & 0.7 \\
\hline Jun-17 & 1.1 & 0.6 & -0.5 & 0.8 & -0.6 & 0.2 & 0.0 & 0.6 \\
\hline Jul-17 & 1.9 & 0.5 & -0.8 & 0.4 & -0.8 & 0.1 & 0.5 & 0.5 \\
\hline Aug-17 & 4.0 & 1.6 & -2.6 & 1.1 & -2.0 & 0.7 & 2.1 & 1.5 \\
\hline Sep-17 & 6.0 & 1.9 & -3.8 & 1.2 & -2.6 & 0.7 & 3.6 & 1.8 \\
\hline Oct-17 & 11.4 & 2.4 & -8.0 & 1.6 & -2.6 & 0.9 & 7.6 & 2.0 \\
\hline Nov-17 & 18.3 & 2.5 & -15.1 & 1.9 & -1.6 & 0.9 & 10.0 & 2.2 \\
\hline Dec-17 & 8.3 & 2.1 & -6.8 & 1.5 & -2.4 & 0.6 & 3.8 & 1.9 \\
\hline Jan-18 & 15.5 & 4.4 & -13.9 & 3.9 & -1.0 & 0.7 & 6.6 & 2.7 \\
\hline Feb-18 & 19.0 & 1.6 & -17.8 & 1.7 & 0.2 & 0.5 & 6.3 & 0.8 \\
\hline Mar-18 & 6.7 & 1.3 & -6.5 & 1.3 & -1.0 & 0.4 & 0.0 & 0.9 \\
\hline Apr-18 & 6.3 & 1.3 & -6.1 & 1.3 & -1.2 & 0.4 & -0.7 & 0.9 \\
\hline May-18 & 6.8 & 1.4 & -6.6 & 1.4 & -1.5 & 0.4 & 0.1 & 0.9 \\
\hline Jun-18 & 6.3 & 1.4 & -6.1 & 1.4 & -1.3 & 0.4 & -0.4 & 1.0 \\
\hline Jul-18 & 6.1 & 1.3 & -6.3 & 1.4 & -1.3 & 0.4 & -0.5 & 1.0 \\
\hline Aug-18 & 6.0 & 1.5 & -5.8 & 1.4 & -1.2 & 0.4 & -0.4 & 1.0 \\
\hline Sep-18 & 6.2 & 1.5 & -6.0 & 1.4 & -1.2 & 0.4 & -0.1 & 1.0 \\
\hline Oct-18 & 6.9 & 1.6 & -6.6 & 1.6 & -1.4 & 0.4 & 0.2 & 1.0 \\
\hline Nov-18 & 11.2 & 4.8 & -10.7 & 4.6 & -1.5 & 0.5 & 2.6 & 1.8 \\
\hline Dec-18 & 9.9 & 2.3 & -9.6 & 2.3 & -1.4 & 0.5 & 1.6 & 1.2 \\
\hline Jan-19 & 17.5 & 6.7 & -16.9 & 6.4 & -0.8 & 0.5 & 4.2 & 2.4 \\
\hline Feb-19 & 11.3 & 2.5 & -11.1 & 2.5 & -1.0 & 0.4 & 0.5 & 1.4 \\
\hline Mar-19 & 12.1 & 2.6 & -11.9 & 2.6 & -0.9 & 0.4 & -0.1 & 1.4 \\
\hline Apr-19 & 11.8 & 3.0 & -11.6 & 2.9 & -0.9 & 0.4 & -0.5 & 1.5 \\
\hline
\end{tabular}

Table S6: Savonnieres colour variations through the experiment time. The variation of colour parameters $\Delta \mathrm{E}_{\mathrm{ab}}, \Delta \mathrm{L}, \Delta \mathrm{a}, \Delta \mathrm{b}$ is calculated from the starting of the ageing test in October 2016 (T0) for January 2017 to April 2020.

\begin{tabular}{|l|l|l|l|l|l|l|}
\hline month & $\phi$ PSII.CO & CO.SD & $\phi$ PSII.DI & DI.SD & $\phi$ PSII.SA & SA.SD \\
\hline Jan-17 & 0.18 & 0.05 & 0.15 & 0.06 & 0.15 & 0.06 \\
\hline Feb-17 & 0.20 & 0.08 & 0.21 & 0.05 & 0.17 & 0.05 \\
\hline Mar-17 & 0.23 & 0.08 & 0.24 & 0.09 & 0.19 & 0.09 \\
\hline Apr-17 & 0.21 & 0.07 & 0.20 & 0.08 & 0.17 & 0.07 \\
\hline May-17 & 0.17 & 0.07 & 0.18 & 0.06 & 0.18 & 0.05 \\
\hline Jun-17 & 0.18 & 0.08 & 0.18 & 0.07 & 0.19 & 0.08 \\
\hline Jul-17 & 0.13 & 0.05 & 0.14 & 0.06 & 0.09 & 0.05 \\
\hline Aug-17 & 0.21 & 0.09 & 0.20 & 0.08 & 0.13 & 0.07 \\
\hline Sep-17 & 0.16 & 0.05 & 0.16 & 0.06 & 0.17 & 0.06 \\
\hline Oct-17 & 0.17 & 0.06 & 0.20 & 0.07 & 0.19 & 0.05 \\
\hline Nov-17 & 0.26 & 0.05 & 0.32 & 0.07 & 0.36 & 0.05 \\
\hline Dec-17 & 0.13 & 0.05 & 0.14 & 0.05 & 0.12 & 0.05 \\
\hline Jan-18 & 0.11 & 0.05 & 0.14 & 0.05 & 0.12 & 0.04 \\
\hline Feb-18 & 0.17 & 0.06 & 0.18 & 0.06 & 0.17 & 0.06 \\
\hline Mar-18 & 0.18 & 0.07 & 0.23 & 0.07 & 0.22 & 0.09 \\
\hline Apr-18 & 0.20 & 0.07 & 0.21 & 0.07 & 0.17 & 0.06 \\
\hline May-18 & 0.22 & 0.08 & 0.24 & 0.09 & 0.22 & 0.07 \\
\hline Jun-18 & 0.29 & 0.10 & 0.32 & 0.10 & 0.20 & 0.09 \\
\hline Jul-18 & 0.26 & 0.06 & 0.24 & 0.09 & 0.21 & 0.08 \\
\hline Aug-18 & 0.24 & 0.08 & 0.25 & 0.09 & 0.23 & 0.08 \\
\hline Sep-18 & 0.22 & 0.08 & 0.22 & 0.08 & 0.20 & 0.07 \\
\hline Oct-18 & 0.22 & 0.07 & 0.22 & 0.08 & 0.22 & 0.08 \\
\hline Nov-18 & 0.19 & 0.06 & 0.19 & 0.07 & 0.20 & 0.07 \\
\hline Dec-18 & 0.14 & 0.06 & 0.13 & 0.05 & 0.12 & 0.05 \\
\hline Jan-19 & 0.16 & 0.05 & 0.13 & 0.04 & 0.18 & 0.06 \\
\hline Feb-19 & 0.20 & 0.08 & 0.20 & 0.06 & 0.18 & 0.06 \\
\hline Mar-19 & 0.18 & 0.08 & 0.19 & 0.06 & 0.16 & 0.07 \\
\hline Apr-19 & 0.22 & 0.07 & 0.22 & 0.07 & 0.21 & 0.07 \\
\hline
\end{tabular}

Table S7: Chlorophyll $a$ fluorescence measured with $\phi$ PSII from January 2017 to April 2019. 


\begin{tabular}{|l|l|l|l|l|l|l|}
\hline month & CO Mean & CO SD & DI Mean & DI SD & SA Mean & SA SD \\
\hline Mar-17 & 0.00 & 0.00 & 0.00 & 0.00 & 0.00 & 0.00 \\
\hline May-17 & 0.08 & 0.08 & 0.08 & 0.08 & 0.08 & 0.08 \\
\hline Jul-17 & 0.10 & 0.14 & 0.39 & 0.18 & 0.49 & 0.14 \\
\hline Aug-17 & 0.07 & 0.07 & 0.51 & 0.22 & 0.59 & 0.15 \\
\hline Sep-17 & 0.05 & 0.07 & 0.29 & 0.12 & 0.94 & 0.20 \\
\hline Oct-17 & 0.50 & 0.06 & 0.33 & 0.24 & 2.34 & 0.56 \\
\hline Nov-17 & 1.17 & 0.84 & 1.85 & 1.75 & 3.19 & 1.03 \\
\hline Dec-17 & 1.60 & 0.31 & 1.55 & 0.93 & 1.29 & 0.14 \\
\hline Jan-18 & 1.01 & 0.38 & 1.00 & 0.43 & 1.96 & 0.24 \\
\hline Feb-18 & 1.04 & 0.12 & 0.80 & 0.29 & 2.06 & 0.30 \\
\hline Mar-18 & 0.35 & 0.07 & 1.08 & 0.49 & 1.86 & 0.66 \\
\hline Apr-18 & 0.83 & 0.14 & 0.68 & 0.25 & 1.47 & 0.48 \\
\hline May-18 & 0.92 & 0.15 & 1.45 & 0.39 & 2.75 & 0.44 \\
\hline Jun-18 & 0.75 & 0.25 & 1.15 & 0.26 & 1.88 & 0.27 \\
\hline Jul-18 & 0.70 & 0.20 & 1.00 & 0.35 & 2.00 & 0.36 \\
\hline Aug-18 & 0.98 & 0.37 & 0.68 & 0.30 & 2.80 & 0.52 \\
\hline Sep-18 & 1.15 & 0.07 & 1.88 & 0.82 & 2.88 & 0.36 \\
\hline Oct-18 & 0.73 & 0.12 & 0.84 & 1.06 & 2.19 & 0.32 \\
\hline Nov-18 & 0.83 & 0.30 & 3.35 & 0.36 & 3.72 & 0.39 \\
\hline Dec-18 & 2.38 & 0.29 & 2.81 & 0.47 & 6.01 & 0.42 \\
\hline Jan-19 & 2.25 & 0.64 & 2.65 & 0.89 & 4.26 & 0.80 \\
\hline Feb-19 & 1.34 & 0.33 & 2.02 & 0.24 & 4.69 & 0.64 \\
\hline Mar-19 & 2.34 & 1.14 & 0.73 & 0.12 & 5.09 & 0.90 \\
\hline
\end{tabular}

Table S8: Chlorophyll- $a$ content $\left(\mu \mathrm{g} . \mathrm{cm}^{-2}\right)$ extracted by ethanol and measured by spectrophotometry at $665 \mathrm{~nm}$ wavelength. Mean and Standard deviation have been calculated from triplicates. for every month and for Courville (CO). Ditrupa (DI) and Savonnieres (SA) limestones.

\begin{tabular}{lllcll}
\hline Stone sample & Hg porosity $(\%)$ & \multicolumn{4}{c}{ Hg intrusion $\left(\mathrm{mL} . \mathrm{g}^{-1}\right)$ for pore access radii } \\
\cline { 3 - 6 } & & $>10 \mu \mathrm{m}$ & $10-1 \mu \mathrm{m}$ & $1-0.1 \mu \mathrm{m}$ & $<0.1 \mu \mathrm{m}$ \\
\hline CO-control & 25.7 & 0.007 & 0.005 & 0.046 & 0.072 \\
CO-10 m & 23.4 & 0.003 & 0.003 & 0.044 & 0.054 \\
CO-16 m & 24.3 & 0.004 & 0.001 & 0.043 & 0.072 \\
CO-26 m & 22.5 & 0.002 & 0.001 & 0.023 & 0.081 \\
& & & & & \\
DI-control & 22.9 & 0.014 & 0.044 & 0.033 & 0.022 \\
DI-10 m & 17.3 & 0.006 & 0.006 & 0.050 & 0.016 \\
DI-16 m & 20.2 & 0.005 & 0.007 & 0.059 & 0.028 \\
DI-26 m & 17.9 & 0.003 & 0.003 & 0.057 & 0.023 \\
& & & & & \\
SA control & 36.2 & 0,047 & 0,087 & 0,069 & 0,026 \\
SA-10 m & 24.1 & 0.013 & 0.059 & 0.030 & 0.020 \\
SA-16 m & 23.5 & 0.013 & 0.068 & 0.028 & 0.010 \\
SA-26 m & 25.8 & 0.027 & 0.047 & 0.032 & 0.022 \\
\hline
\end{tabular}

Table S9: Mercury porosimetry for control (before ageing), at 10, 16 and 26 months of ageing. $\mathrm{Hg}$ porosity (\%) is presented and Mercury intrusion for four classes of pore access radii: superior to $10 \mu \mathrm{m}$, between 10 and $1 \mu \mathrm{m}$, between 1 and $0.1 \mu \mathrm{m}$ and inferior to $0.01 \mu \mathrm{m}\left(\mathrm{mL} \cdot \mathrm{g}^{-1}\right)$. 


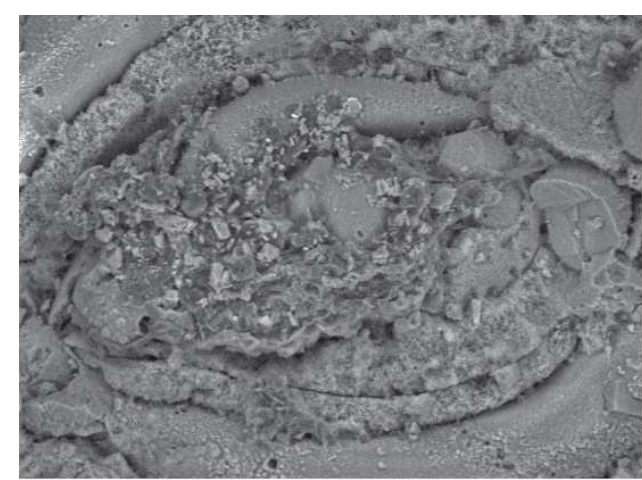

(a)

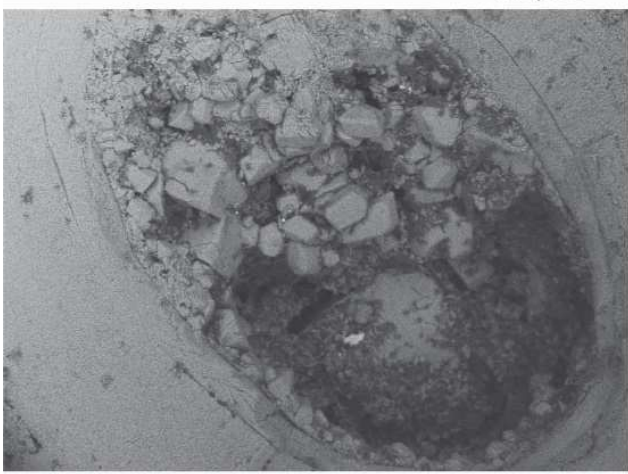

(c)

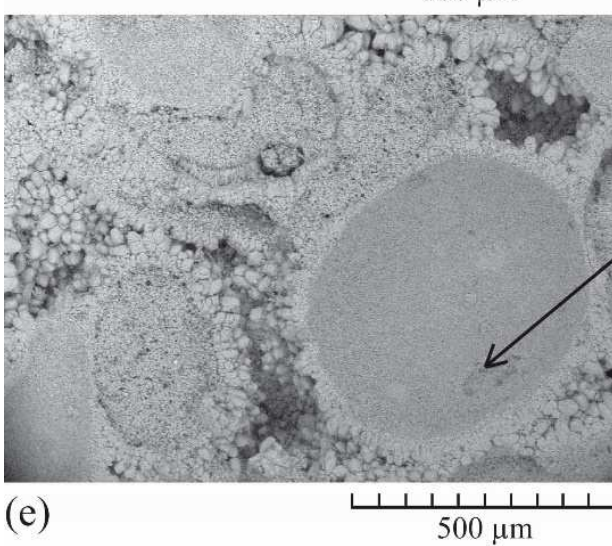

(f)

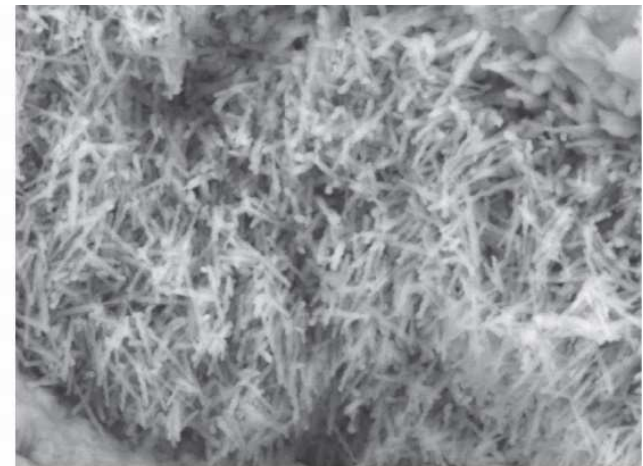

(b)
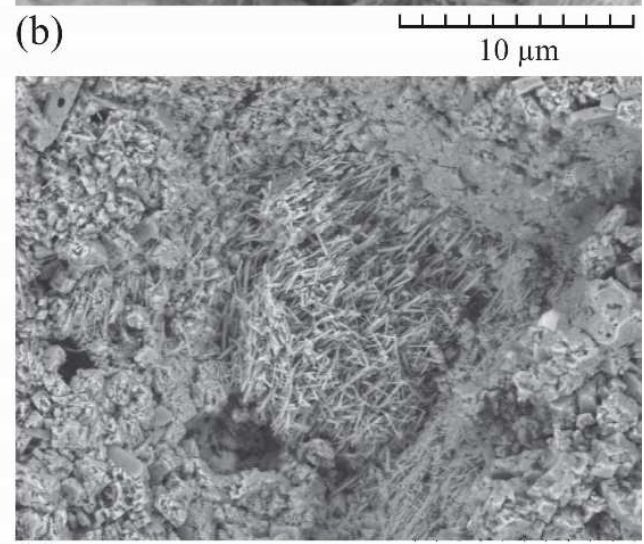

(d)

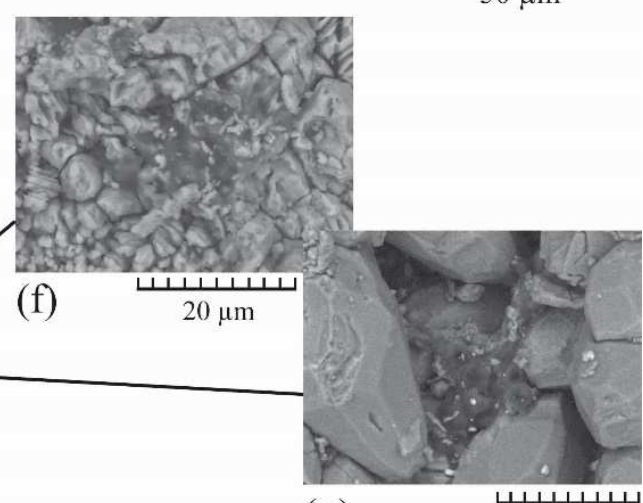

$(\mathrm{g})$

$$
30 \mu \mathrm{m}
$$

Figure S2: SEM images of Courville stone (a-b), Ditrupa stone (c-d) and Savonnieres stone (e-f-g) at month 10. On the Courville, the microbial growth was observed in the porosity of microfossils and micro-needles of calcite formed in the macroporosity. On Ditrupa, patches of microorganisms grew in the micropores and in big Ditrupa worm tubes. On Savonnieres, patches developed in the microporosity of oolit nuclei. 